\title{
Assessment of Heavy Metals Concentration and Enrichment Levels in Soils around Quarries and Barite Mine Sites in Part of Akamkpa and Biase Area, Southeastern Nigeria
}

\author{
Ibu Ochelebe, Gordon Essien Nkebem, Ebenezar Agayina Kudamnya \\ Department of Geology, University of Calabar, Calabar, Nigeria \\ Email: iochelebe@yahoo.com
}

How to cite this paper: Ochelebe, I., Nkebem, G. E., \& Kudamnya, E. A. (2020). Assessment of Heavy Metals Concentration and Enrichment Levels in Soils around Quarries and Barite Mine Sites in Part of Akamkpa and Biase Area, Southeastern Nigeria. Journal of Geoscience and Environment Protection, 8, 107-128.

https://doi.org/10.4236/gep.2020.88009

Received: May 17, 2020

Accepted: August 28, 2020

Published: August 31, 2020

Copyright $\odot 2020$ by author(s) and Scientific Research Publishing Inc. This work is licensed under the Creative Commons Attribution International License (CC BY 4.0).

http://creativecommons.org/licenses/by/4.0/

\section{(c) (i) Open Access}

\begin{abstract}
Geochemical investigation of the soils around quarry and barite mine sites in part of Akamkpa and Biase area of Southeastern Nigeria, was carried out to assess the concentration and enrichment levels of some heavy metals and trace elements in the soils. The investigation involved the collection of fifteen (15) soil samples between the depth of $15-30 \mathrm{~cm}$. The samples were dried at room temperature, prepared and analyzed for heavy metals using inductively couple plasma mass spectrometer. The result shows that the concentration of $\mathrm{Co}, \mathrm{Cr}, \mathrm{Nb}, \mathrm{Pb}$ and $\mathrm{Sn}$ were higher than the average shale values around the quarries while $\mathrm{Ba}, \mathrm{Pb}$ and $\mathrm{Sn}$ were higher around the barite mines. The contamination factor indicates low to minimal contamination and low to considerable contamination around the quarries and barite mines respectively. While the Enrichment factor indicates minimal to significant enrichment around the quarries and minimal to extremely high enrichments around the barite mines. The result of the factor analysis and spatial distribution of the heavy metals suggests that the metal concentration and enrichment were controlled by the rock types, weathering and anthropogenic activities around the mine sites.
\end{abstract}

\section{Keywords}

Heavy Metal, Quarry, Barite Mine, Enrichment Factor, Contamination Factor

\section{Introduction}

Heavy metals are common component of rocks and minerals of the earth's crust, which are recycled within the environment through natural processes such as 
weathering and volcanic activities. However, the quest for knowledge and comfort by humans has led to advances in technology and exploitation of the earth's resources, leading to a change from natural cycling of elements, to the anthropogenic addition of heavy metals in soils, water and air. Mining activities have released large quantities of trace elements, volatiles and dust particles into the environment, thus creating potential health and environmental problems.

The existence of heavy metals in our immediate environment and their impacts on human health was initially perceived to be an individual problem arising probably from increased vulnerability of such people to certain kinds of diseases. But with advancement in scientific and medical knowledge, and a steady rise in disorders that are known to be linked with environmental pollution, many have attributed the serious health implications to the excessive build-up of heavy metals in the environment (Huss, 2011; Lenntech, 2011; Martin \& Griswold, 2009; Bond, 2009). Barite mining and quarrying activities have been going on in the Biase and Akampka area for more than two decades, leading to possible release of toxic heavy metals in the area. High levels of heavy metals concentration have been reported around mining district globally (Rafiei et al., 2010; Bölücek, 2007; Sun et al., 2018; Huang et al., 2017) and the health risk associated with high metal concentration on the environment has also been reported (Rahman et al., 2010; Tian, 2009; Oancea et al., 2005; Singh \& Kalamdhad, 2011).

Most barite mining activities are often times associated with the generation of vast quantities of mines rock and mine tailings, and these may eventually elevate levels of sulphates and acidity in soils (Adamu et al., 2015a). In Nigeria, studies have revealed that higher enrichment of heavy metals is recorded around mining and cultivated area (Ochelebe et al., 2017; Nganje et al., 2010). Studies have also shown that, sediment quality has been used as an important indicator of pollution (Zarei et al., 2014; Adamu et al., 2015b) as they are known to be major sinks for various pollutants. Furthermore, the heterogeneous nature of the sediment environment, allows for water to play a significant role in the mobilization of these contaminants.

Past studies around the mining area have been focused on stream sediments associated with barite mines and surface water from ponds within the mines and surrounding streams (Adamu et al., 2015a; Adamu et al., 2015b). Therefore, the present work focuses on the assessment of the concentration and enrichment levels of heavy metals (Aluminium (Al), Antimony (Sb), Arsenic (As), Barium (Ba), Cerium (Ce), Cobalt (Co), Chromium ( $\mathrm{Cr}$ ), Copper $(\mathrm{Cu})$, Iron $(\mathrm{Fe})$, manganese (Mn), Molybdenum (Mo), Nickel (Ni), Niobium ( $\mathrm{Nb}$ ), Lead $(\mathrm{Pb})$, Scandium (Sc), Strontium (Sr), Thorium (Th), Tin (Sn), Vanadium (V) and Zinc $(\mathrm{Zn})$ ) in the soils within the vicinity of mining sites around Biase and Akamkpa Area.

\section{Description of Study Area}

The study area lies within longitudes $8^{\circ} 00^{\prime} \mathrm{E}$ to $8^{\circ} 30^{\prime} \mathrm{E}$ and latitudes $5^{\circ} 20^{\prime} \mathrm{N}$ to 
$5^{\circ} 45^{\prime} \mathrm{N}$. Accessibility to the area is through a major road, the Calabar-Ikom highway, minor roads such as; Unyanga-Ifunkpa road, Ayaba-Ikot Okpora road, Abini-Agwuagune roads, and various footpaths also led to sample locations. The area is drained by a major river, the Cross River and some smaller rivers and streams (Figure 1). Some of the streams are; Ikpaya, Ayiboniong, Eyuma, Ageden, Ekpendu-Iwuru, Efajene and Ugbam streams. Most of the streams flow in the NE-SW direction. The relief of the area is undulating, with some minor hills and valleys. The mean annual rain fall in the area was reported to be about 2300 $\mathrm{mm}$ (CRBDA, 2008). The temperature ranges between $25^{\circ} \mathrm{C}$ and $35^{\circ} \mathrm{C}$ (Iloeje, 1991).

\section{Geology}

The area is underlain by Oban Massif to the south and Ikom-Mamfe Embayment to the north. The rocks of the southern part are composed of gneisses associated with quartzites and intruded by pegmatites. The gneiss grades into schist which is intruded by granodiorite and pegmatite in some parts. A sharp contact exists between the schist and calcareous sandstone in the north-western part of the study area (Figure 2). Geochemical studies of the gneisses by Ekwueme \& Onyeagocha (1986) shows that they are metasediments of shale-greywacke. The granodiorite is the most extensive intrusive in the study area. The rocks are coarse-grained, non-foliated and have a sharp contact with the schist. Geochemical studies of the schists at Ikot-Ana show them to consist typically of metasediments, which have a composition characteristic of phyllites and semi-phyllites (Ekwueme, 1995).

\section{Methodology}

A total of fifteen (15) soil samples were collected within and around barite mines (6 samples) and quarries (9 samples), using hand auger at depth $15-30 \mathrm{~cm}$. The samples were dried at room temperature. The dried samples were disaggregated using mortar and pestle and then sieved through the 200 mesh size. $0.5 \mathrm{~g}$ of each powdered sample was weighed into $100 \mathrm{ml}$ glass beakers and digested using hot acid extraction method. The digested samples were analysed for $\mathrm{Al}, \mathrm{Sb}, \mathrm{As}, \mathrm{Ba}$, $\mathrm{Ce}, \mathrm{Co}, \mathrm{Cr}, \mathrm{Cu}, \mathrm{Fe}, \mathrm{Mn}, \mathrm{Mo}, \mathrm{Ni}, \mathrm{Nb}, \mathrm{Pb}, \mathrm{Sc}, \mathrm{Sr}, \mathrm{Th}, \mathrm{Sn}, \mathrm{V}$ and $\mathrm{Zn}$. The analysis was done using a Perkin Elmer Elan 6000/9000 Inductively Couple Plasma Mass Spectrometry (ICP-MS) in Acme laboratory, Canada. Factor analysis was carried out for the twenty variables in the soil sample in order to determine the sources of metal concentration, as well as the factors controlling them.

Also contamination factor (FC) and enrichment factor (EF) (Table 1) were computed for each element at all the locations to evaluate the degree of contamination. The CF was calculated using Equation (1) (Harikumar \& Jisha, 2010).

$$
C F=\frac{C_{m}}{B_{n}}
$$

where; $C_{m}=$ Concentration of element in the soil sample 

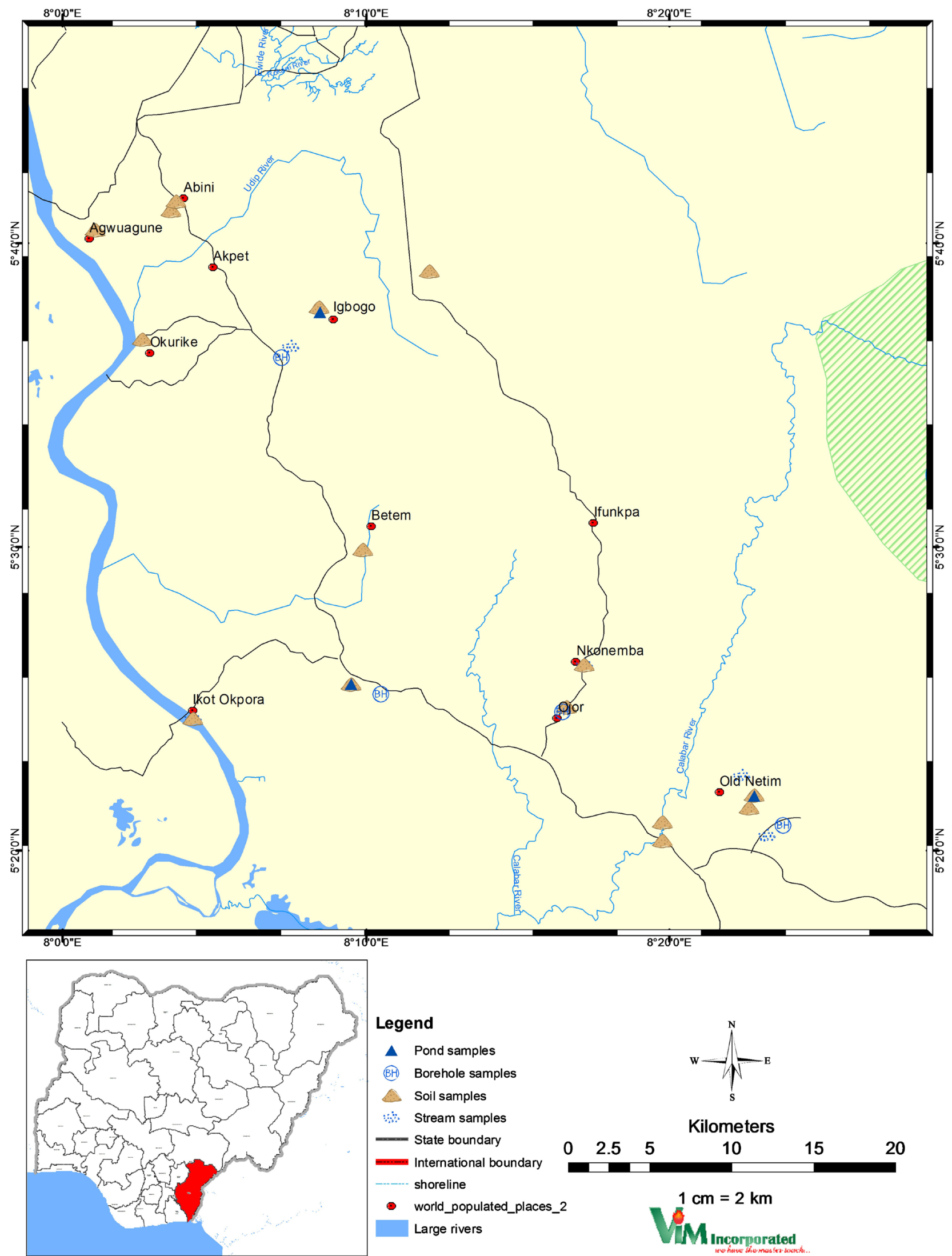

\section{Legend}

A Pond samples

(BAi) Borehole samples

Soil samples

Stream samples

- State boundary

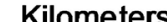

=.... International boundary

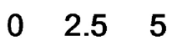

10

15

20

--- shoreline

- world_populated_places_2

Large rivers

$1 \mathrm{~cm}=2 \mathrm{~km}$

\section{覃}

Incorporated

Figure 1. Map of the study area. 


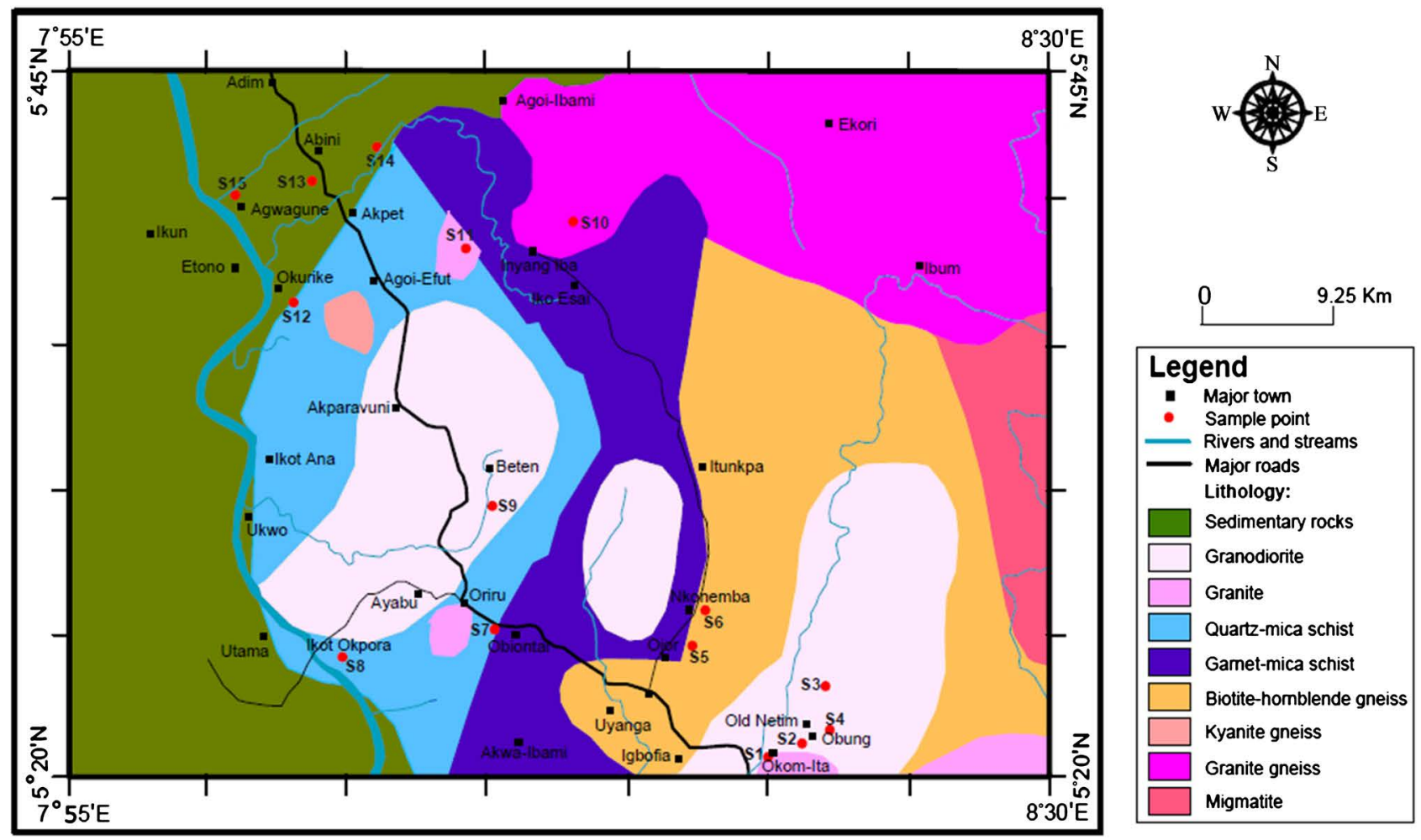

Figure 2. Geologic Map of the Study Area with sample locations (Modified from Ekwueme et al., 1995).

Table 1. Classes of contamination and enrichment factors in soil.

\begin{tabular}{cccc}
\hline \multicolumn{2}{c}{ Contamination Factor $^{\mathrm{a}}$} & \multicolumn{2}{c}{ Enrichment Factor $^{\mathrm{b}}$} \\
\hline $\mathrm{CF}$ indices & Degree of contamination & EF indices & Degree of enrichment \\
\hline $\mathrm{CF}<1$ & Low contamination, & $\mathrm{EF}<2$ & Deficiency to minimal enrichment \\
$1 \leq \mathrm{CF} \leq 3$ & Moderate contamination & $2 \leq \mathrm{EF} \leq 5$ & Moderate enrichment \\
$3 \leq \mathrm{CF} \leq 6$ & Considerable contamination & $5 \leq \mathrm{EF} \leq 20$ & Significant enrichment \\
$\mathrm{CF} \geq 6$ & Very high contamination & $20 \leq \mathrm{EF} \leq 40$ & Very high enrichment \\
& & $\mathrm{EF}>40$ & Extremely high enrichment \\
\hline
\end{tabular}

${ }^{\mathrm{a}}$ (After Harikumar \& Jisha, 2010); ${ }^{\mathrm{b}}$ (After Sutherland, 2000).

$B_{n}=$ Background concentration of the element considered.

The average shale composition of each element, published by Wedepohl (1971).

The EF for the heavy metals was calculated using the expression of Simex \& Helz (1981);

$$
\mathrm{EF}=\left(\mathrm{M}_{\text {sample }} / \mathrm{Fe}_{\text {sample }}\right) /\left(\mathrm{M}_{\text {ref }} / \mathrm{Fe}_{\text {ref }}\right)
$$

where; $\mathrm{M}_{\text {sample }}$ is the concentration of heavy metal $\mathrm{M}$ in sample.

$\mathrm{Fe}_{\text {sample }}$ is the concentration of iron in sample.

$\mathrm{M}_{\text {ref }}$ is the background concentration of heavy metal $\mathrm{M}$.

$\mathrm{Fe}_{\mathrm{ref}}$ is the background concentration of iron. 


\section{Results and Discussion}

Statistical summary of heavy metal contents in the sampled soils were presented in Table 2. It shows the range and mean values of heavy metal concentrations from the study, in comparison with average shale values (Wedepohl, 1971). The result shows that, all the heavy metals were below the average shale values, except $\mathrm{Ba}$ and $\mathrm{Sn}$ which are greater in both quarry and barite mine areas and $\mathrm{Co}$, $\mathrm{Cr}$ and $\mathrm{Nb}$ which are greater in the quarry area and $\mathrm{Pb}$ which is greater in the barite area. Indicating that the mineralization and subsequent release of these metals into the soils were due to natural processes such as weathering. This is in agreement in assertions by Adamu et al. (2015a). Initial assessment reveals mean heavy metals dominance in the order $\mathrm{Ba}>\mathrm{Mn}>\mathrm{Cr}>\mathrm{Sr}>\mathrm{V}>\mathrm{Zn}>\mathrm{Ce}>\mathrm{Pb}>$ $\mathrm{Co}>\mathrm{Nb}>\mathrm{Cu}>\mathrm{Ni}>\mathrm{Th}>\mathrm{Sc}>\mathrm{Sn}>\mathrm{As}>\mathrm{Mo}>\mathrm{Al}>\mathrm{Fe}>\mathrm{Sb}$ aroundthe quarries and $\mathrm{Ba}>\mathrm{Sr}>\mathrm{Mn}>\mathrm{V}>\mathrm{Cr}>\mathrm{Pb}>\mathrm{Ce}>\mathrm{Zn}>\mathrm{Cu}>\mathrm{Nb}>\mathrm{Ni}>\mathrm{Sc}>\mathrm{Co}>\mathrm{Th}>$ $\mathrm{As}>\mathrm{Sn}>\mathrm{Mo}>\mathrm{Al}>\mathrm{Fe}>\mathrm{Sb}$ around the barite mines.

Also, it was observed that total heavy metal concentration around the barite

Table 2. Statistical summary of heavy metal concentration in soil samples from the study area.

\begin{tabular}{|c|c|c|c|c|c|c|c|}
\hline \multirow{2}{*}{$\begin{array}{c}\text { Heavy } \\
\text { metals, ppm }\end{array}$} & \multicolumn{3}{|c|}{ Quarry area } & \multicolumn{3}{|c|}{ Barite area } & \multirow{2}{*}{$\begin{array}{c}\text { Average } \\
\text { Shale }\end{array}$} \\
\hline & Min & Max & Mean & Min & $\operatorname{Max}$ & Mean & \\
\hline $\mathrm{Al}$ & 0.140 & 1.400 & 0.440 & 0.190 & 1.140 & 0.700 & 8.8 \\
\hline As & 0 & 4.000 & 2.670 & 0 & 15.000 & 6.000 & 10 \\
\hline $\mathrm{Ba}$ & 174.000 & 817.000 & 506.000 & 175.000 & 7500.000 & 2663.000 & 580 \\
\hline $\mathrm{Ce}$ & 6.000 & 101.000 & 42.500 & 15.000 & 51.000 & 32.800 & 62 \\
\hline Co & 9.500 & 42.900 & 20.200 & 2.200 & 16.800 & 7.780 & 19 \\
\hline $\mathrm{Cr}$ & 18.000 & 236.000 & 110.300 & 6.000 & 227.000 & 89.300 & 90 \\
\hline $\mathrm{Cu}$ & 4.900 & 18.100 & 12.030 & 3.900 & 44.100 & 18.730 & 45 \\
\hline $\mathrm{Fe}$ & 0.080 & 0.620 & 0.240 & 0.040 & 1.110 & 0.420 & 4.72 \\
\hline $\mathrm{Mn}$ & 66.000 & 470.000 & 278.000 & 13.000 & 241.000 & 106.500 & 900 \\
\hline Mo & 0.200 & 1.000 & 0.500 & 0.100 & 3.200 & 1.730 & 3 \\
\hline $\mathrm{Nb}$ & 5.600 & 26.000 & 14.000 & 2.400 & 20.700 & 9.500 & 11 \\
\hline $\mathrm{Ni}$ & 4.000 & 43.200 & 11.000 & 2.500 & 18.700 & 8.900 & 68 \\
\hline $\mathrm{Pb}$ & 7.500 & 39.200 & 21.900 & 9.800 & 116.900 & 44.470 & 20 \\
\hline$S b$ & 0 & 0.400 & 0.200 & 0 & 0.400 & 0.170 & 1.5 \\
\hline Sc & 1.000 & 15.000 & 4.600 & 0 & 21.000 & 8.600 & 13 \\
\hline Sn & 1.300 & 6.800 & 3.350 & 0.400 & 18.400 & 3.200 & 3 \\
\hline $\mathrm{Sr}$ & 15.000 & 183.000 & 79.670 & 39.000 & 209.000 & 110.800 & 300 \\
\hline Th & 2.200 & 20.800 & 10.800 & 2.600 & 12.100 & 7.550 & 12 \\
\hline $\mathrm{V}$ & 21.000 & 155.000 & 65.700 & 8.000 & 228.000 & 99.800 & 130 \\
\hline $\mathrm{Zn}$ & 12.000 & 89.000 & 52.500 & 12.000 & 56.000 & 32.700 & 95 \\
\hline
\end{tabular}


mines were higher compared to those around the quarries. Barite mineralization in the area according to Ekweme \& Akpeke (2012) is structurally controlled, and as such, the presence of these structures could be responsible for the mobilization of these heavy metals and their subsequent enrichment. The spatial distribution pattern of the elements presented in Figure 3 in relation to the geology of the area (Figure 2) suggests a great influence of the underlying rock types. The metals Fe and Sr have their highest concentrations within the sedimentary basin (Figure 3(h) and Figure 3(q)), that may serve as sink for these metals (Zarei et al., 2014; Adamu et al., 2015a). This may be due to the fact that the sedimentary basin receives materials from the basement, and so these metals may be released and transported from the elevated basement terrains to the lower plains of the basins.

The elements; As, Ba, Cr, Cu, Mo, Pb, Sc, Sn and V, have their concentrations higher around the barite mine (Figure 3(b), Figure 3(c), Figure 3(f), Figure $3(\mathrm{~g})$, Figure $3(\mathrm{j})$, Figure $3(\mathrm{~m})$, Figure $3(\mathrm{o})$, Figure $3(\mathrm{p})$ and Figure $3(\mathrm{~s})$ ) dominated by the presence of gneisses, indicating that they may be associated with rock weathering and barite mining activity. Further, the elements $\mathrm{Mn}$ and $\mathrm{Zn}$ have higher concentration around the quarry sites underlain by the granodiorites (Figure 3(i) and Figure 3(t)), thus indicating that their concentration is as a result of quarrying activity and weathering of granodiorites. The elements $\mathrm{Al}$, $\mathrm{Ce}, \mathrm{Nb}, \mathrm{Ni}$ and $\mathrm{Sb}$ have higher concentrations around the mine areas underlain by schist (Figure 3(a), Figure 3(d), Figure 3(k), Figure 3(l) and Figure 3(n)), suggesting that they are released during the weathering of schist.

\subsection{Contamination Factor (CF)}

The summary of computed CF is presented in Table 3. The result shows that, based on the mean $\mathrm{CF}$, the quarry area is lowly contaminated with $\mathrm{Al}, \mathrm{As}, \mathrm{Ba}$, $\mathrm{Ce}, \mathrm{Cu}, \mathrm{Fe}, \mathrm{Mn}, \mathrm{Mo}, \mathrm{Ni}, \mathrm{Sb}, \mathrm{Sc}, \mathrm{Sr} \mathrm{Th}, \mathrm{V}$ and $\mathrm{Zn}$, and moderately contaminated with $\mathrm{Co}, \mathrm{Cr}, \mathrm{Nb}, \mathrm{Pb}$, and $\mathrm{Sn}$. While, the barite mine areas are lowly contaminated with $\mathrm{Al}, \mathrm{As}, \mathrm{Ce}, \mathrm{Co}, \mathrm{Cr}, \mathrm{Cu}, \mathrm{Fe}, \mathrm{Mn}, \mathrm{Mo}, \mathrm{Nb}, \mathrm{Ni}, \mathrm{Sb}, \mathrm{Sc}, \mathrm{Sr} \mathrm{Th}, \mathrm{V}$ and $\mathrm{Zn}$, moderately contaminated with $\mathrm{Pb}$ and $\mathrm{Sn}$, and considerably contaminated with $\mathrm{Ba}$. Generally, the distribution of CF suggests the influence of geology and activities around the sites, since the locations within and around the barite mines are underlain by gneissic rocks and considerably contaminated with Ba, compared with those around the quarry sites, that are mostly underlain by granodiorite.

\subsection{Enrichment Factor}

The summary of the computed EF for all the soil samples are presented in Table 4. The result shows that the quarry area is deficient and minimally enriched with $\mathrm{Al}$, As and $\mathrm{Sb}$, moderately enriched with $\mathrm{Cu}, \mathrm{Mo}$ and $\mathrm{Ni}$, significantly enriched with $\mathrm{Ba}, \mathrm{Ce}, \mathrm{Cr}, \mathrm{Mn}, \mathrm{Sc}, \mathrm{Sn}, \mathrm{Sr}, \mathrm{Th}, \mathrm{V}$ and $\mathrm{Zn}$, with very high enrichment in Co, $\mathrm{Nb}$ and $\mathrm{Pb}$. While the barite mine area is deficient in $\mathrm{Al}$, moderately enriched in $\mathrm{As}, \mathrm{Mn}, \mathrm{Ni}, \mathrm{Sb}$ and $\mathrm{Zn}$, significantly enriched in $\mathrm{Ce}, \mathrm{Co}, \mathrm{Cu}, \mathrm{Mn}, \mathrm{Mo}$ and $\mathrm{Nb}$, 


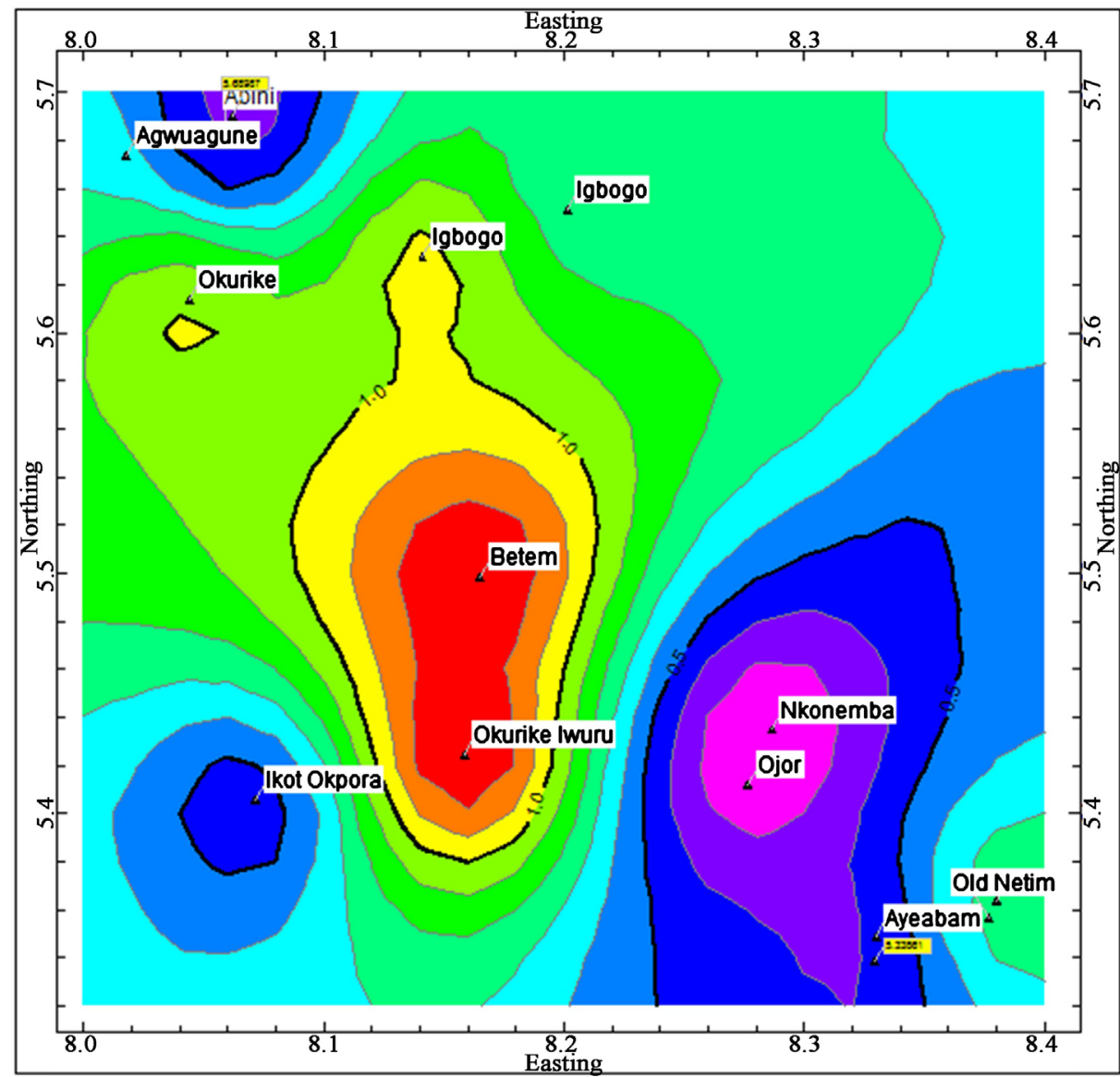

(a)

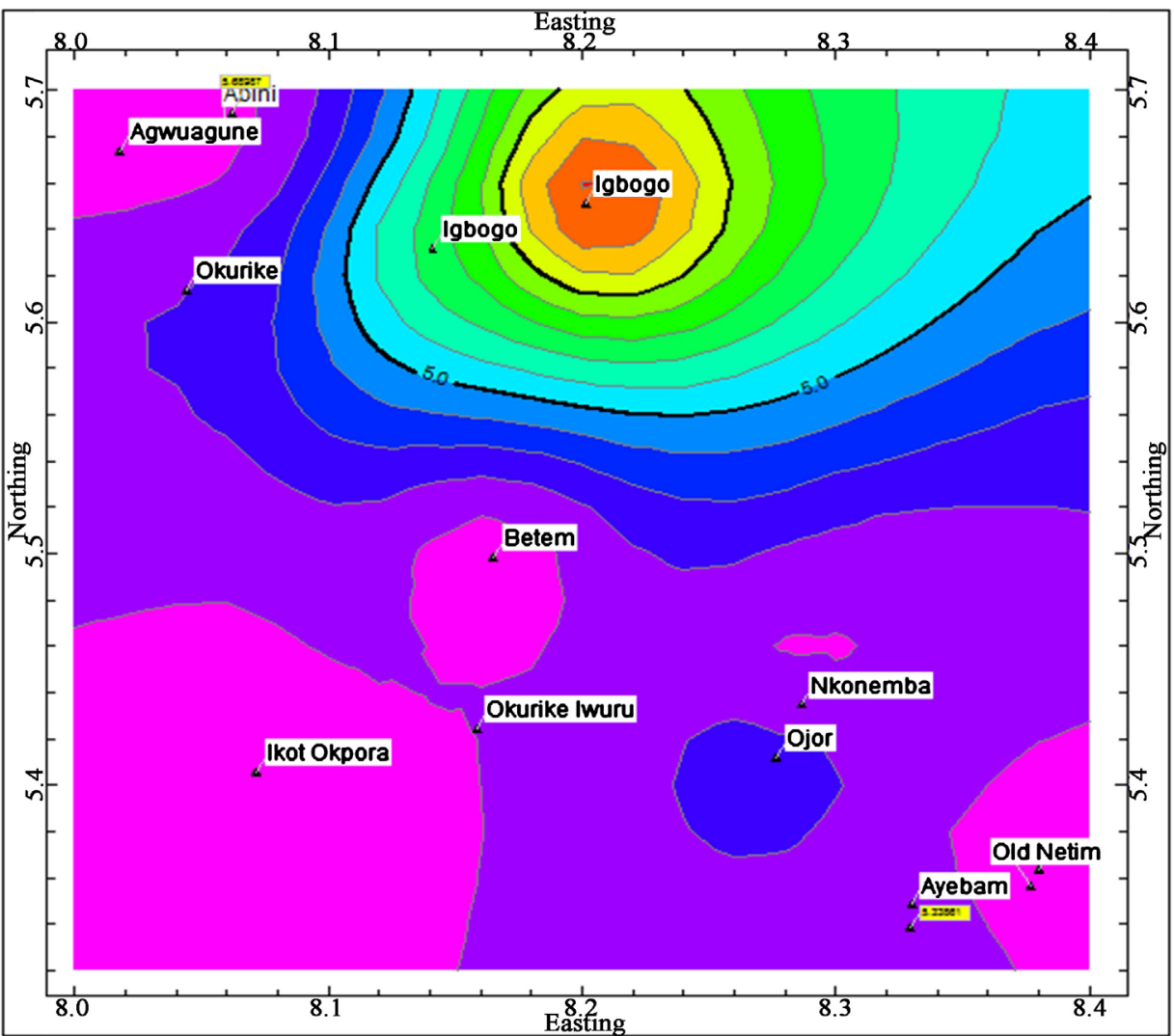

(b)

\begin{tabular}{|c|}
\hline s (ppm) \\
\hline 14.0 \\
\hline 13.0 \\
\hline 12.0 \\
\hline 11.0 \\
\hline 10.0 \\
\hline 9.0 \\
\hline 8.0 \\
\hline 7.0 \\
\hline 6.0 \\
\hline 5.0 \\
4.0 \\
3.0 \\
2.0 \\
1.0 \\
0.0 \\
\hline
\end{tabular}




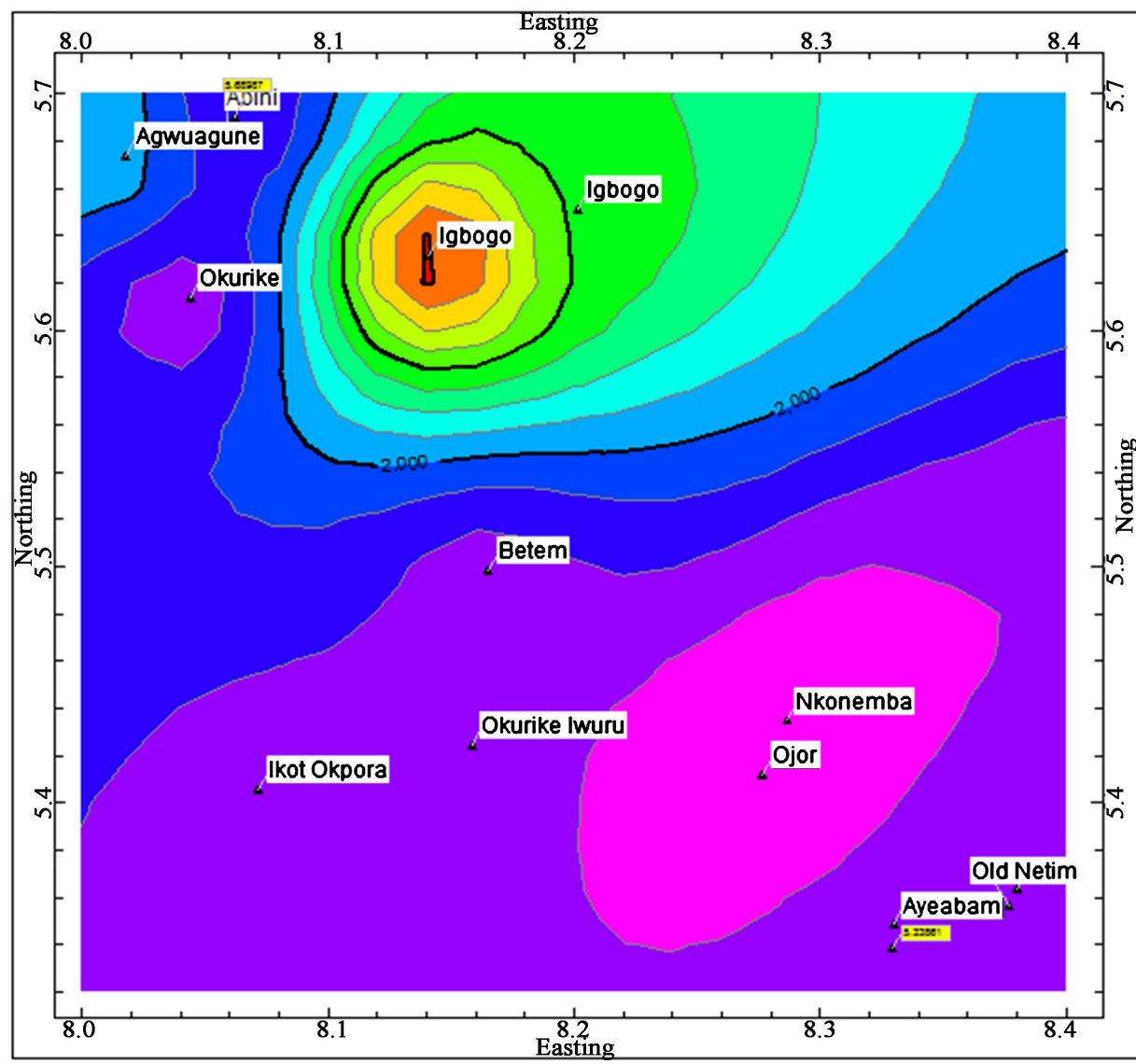

(c)
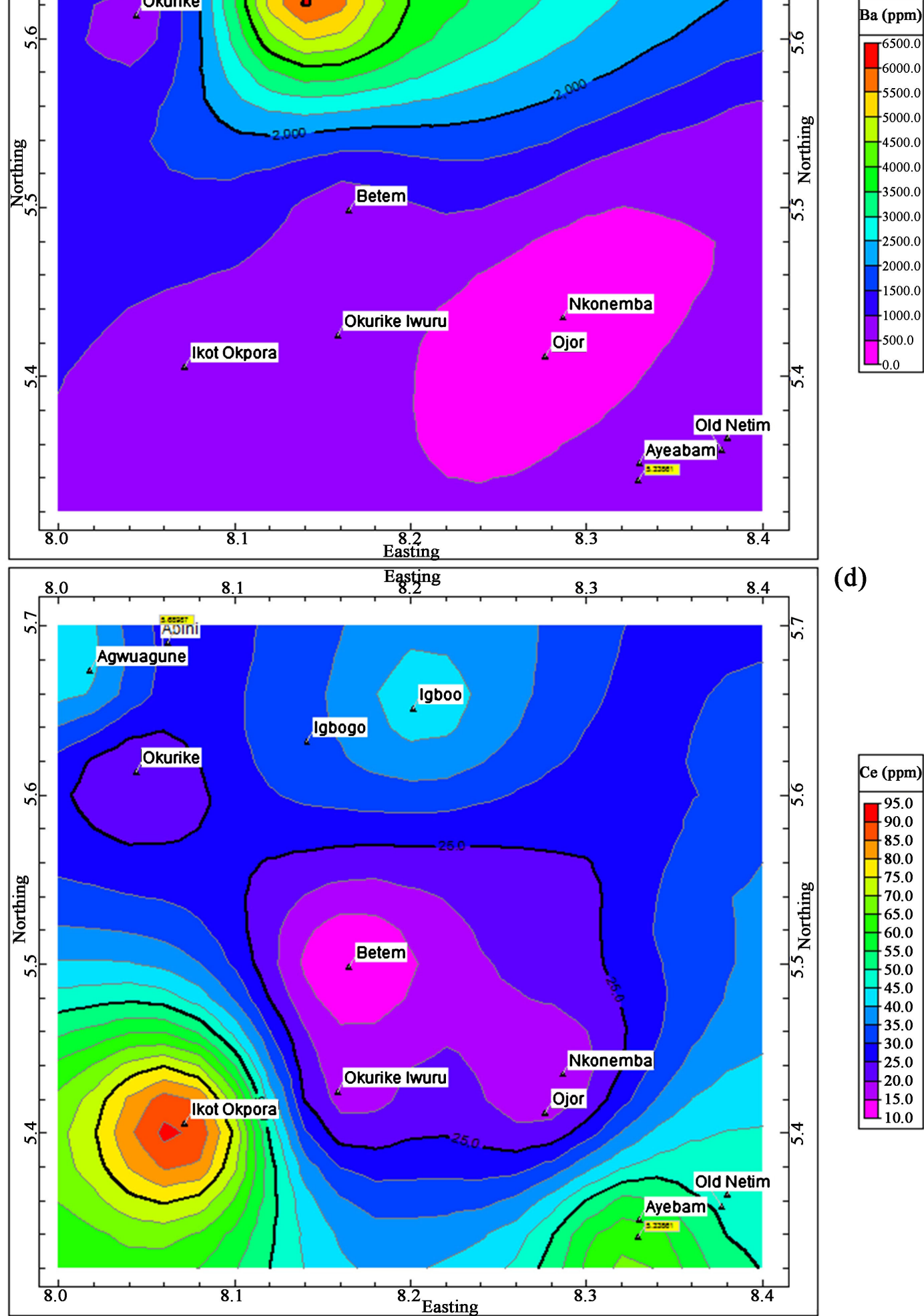

(d)

\begin{tabular}{|l|}
\hline Ce (ppm) \\
\hline 95.0 \\
990.0 \\
85.0 \\
\hline 80.0 \\
75.0 \\
770.0 \\
65.0 \\
\hline 60.0 \\
\hline 55.0 \\
\hline 50.0 \\
\hline 45.0 \\
\hline 40.0 \\
335.0 \\
330.0 \\
25.0 \\
20.0 \\
15.0 \\
10.0 \\
\hline
\end{tabular}




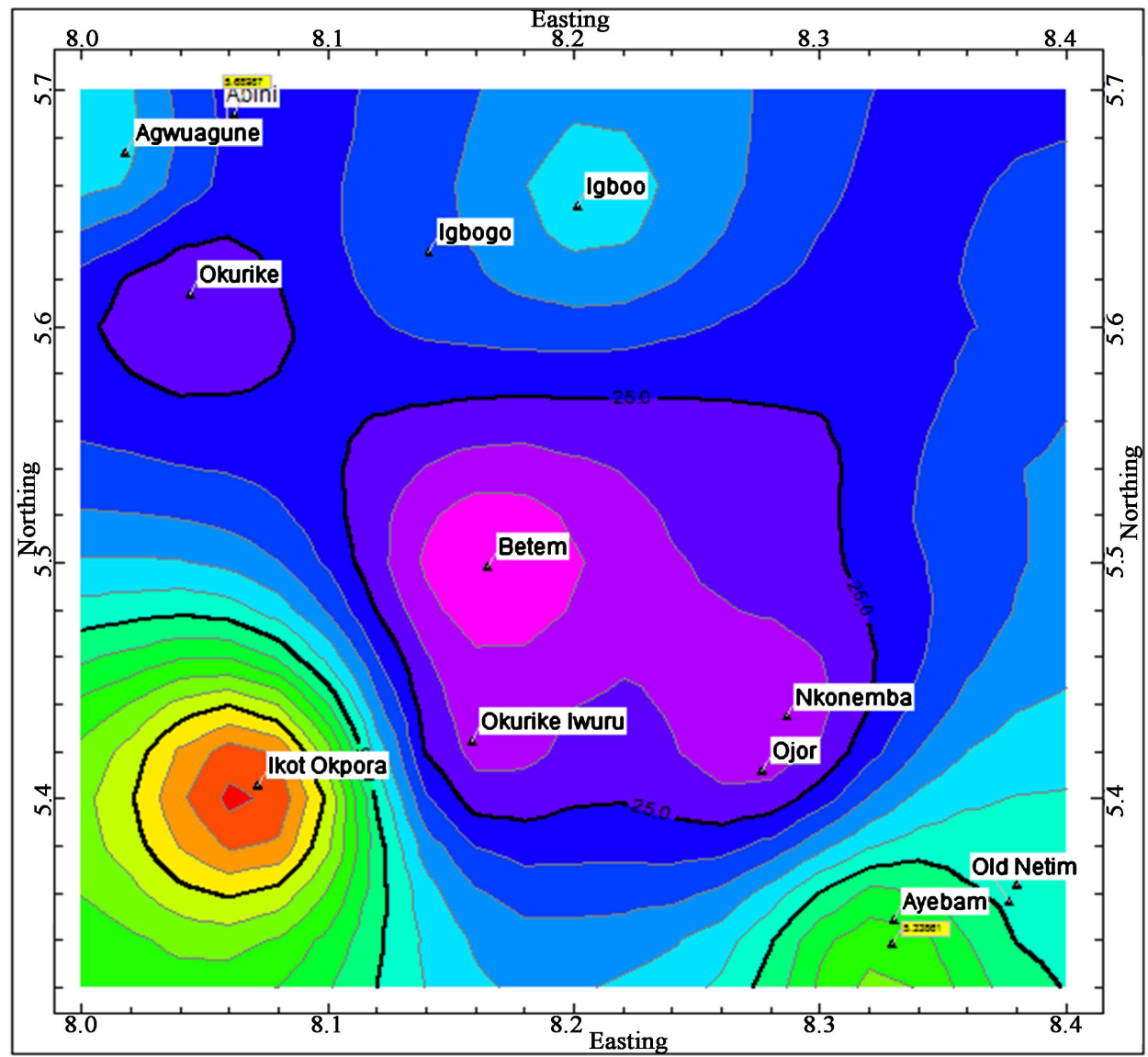

(e)

\begin{tabular}{|r|}
\hline $\operatorname{Ce}(\mathrm{ppm})$ \\
\hline 95.0 \\
\hline 90.0 \\
85.0 \\
\hline 80.0 \\
75.0 \\
770.0 \\
\hline 65.0 \\
\hline 60.0 \\
\hline 55.0 \\
\hline 50.0 \\
\hline 45.0 \\
\hline 40.0 \\
\hline 35.0 \\
30.0 \\
225.0 \\
\hline 20.0 \\
\hline 15.0 \\
10.0 \\
\hline
\end{tabular}

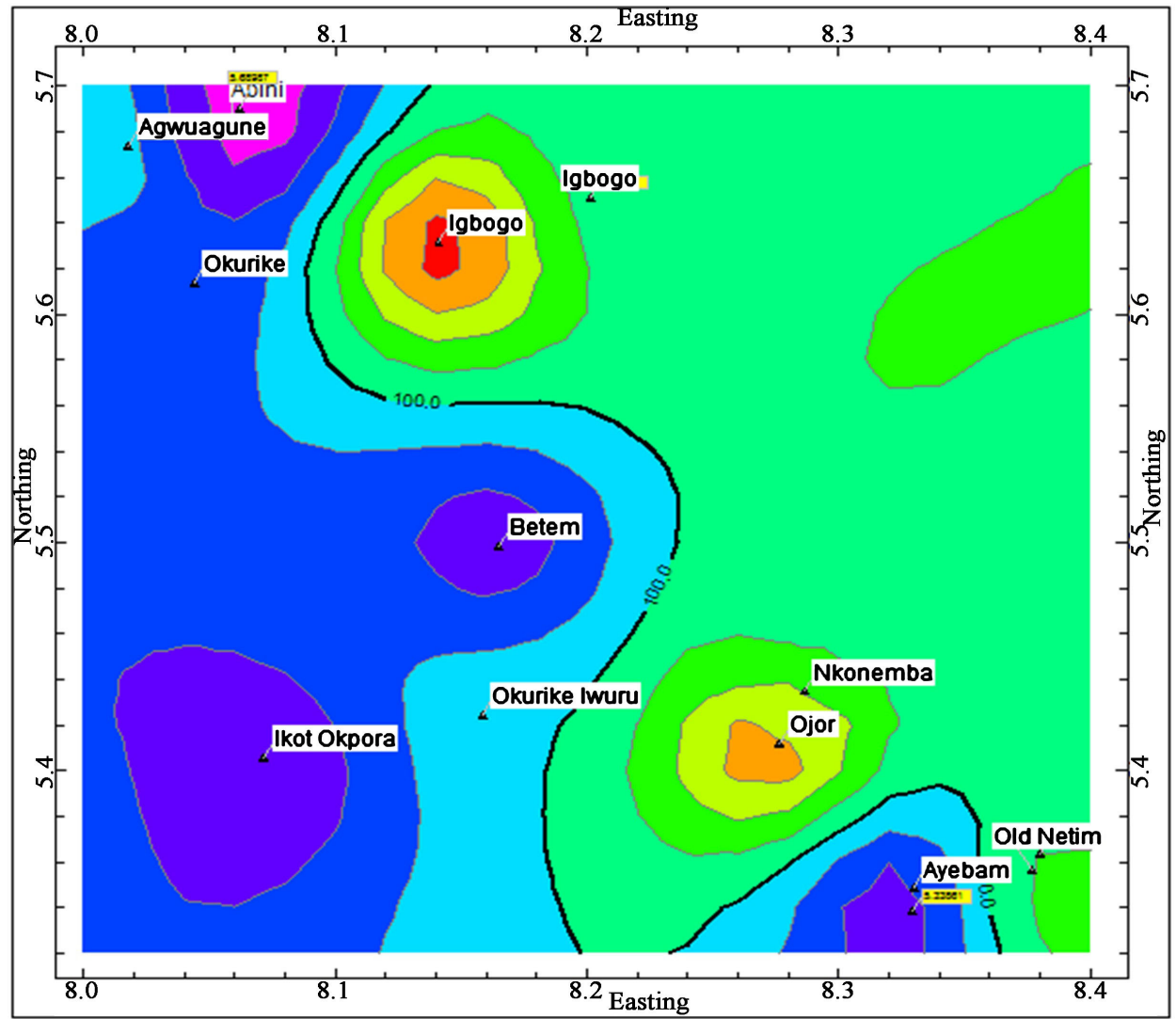

(f)

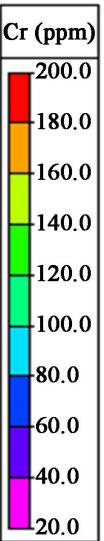




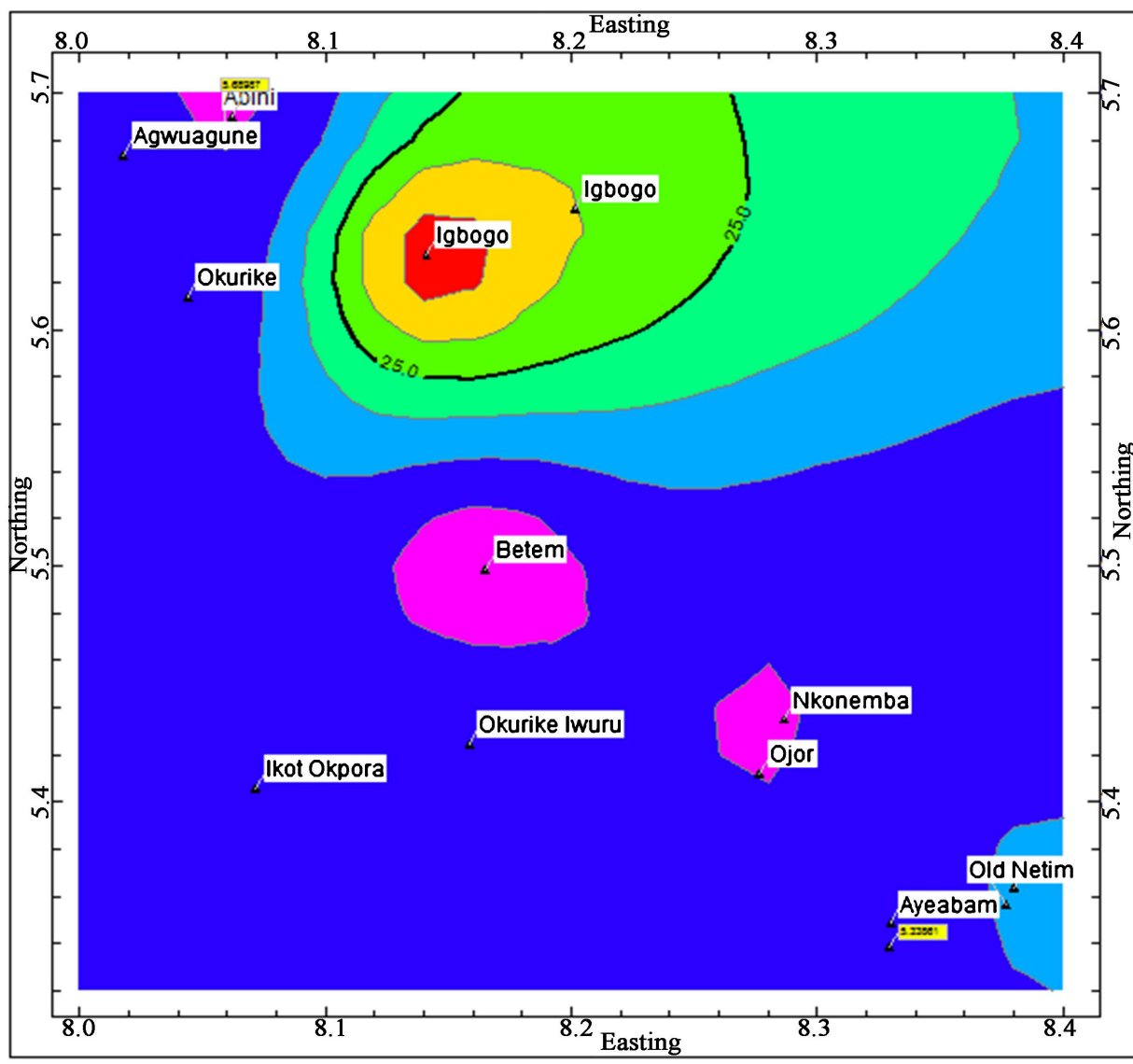

(g)
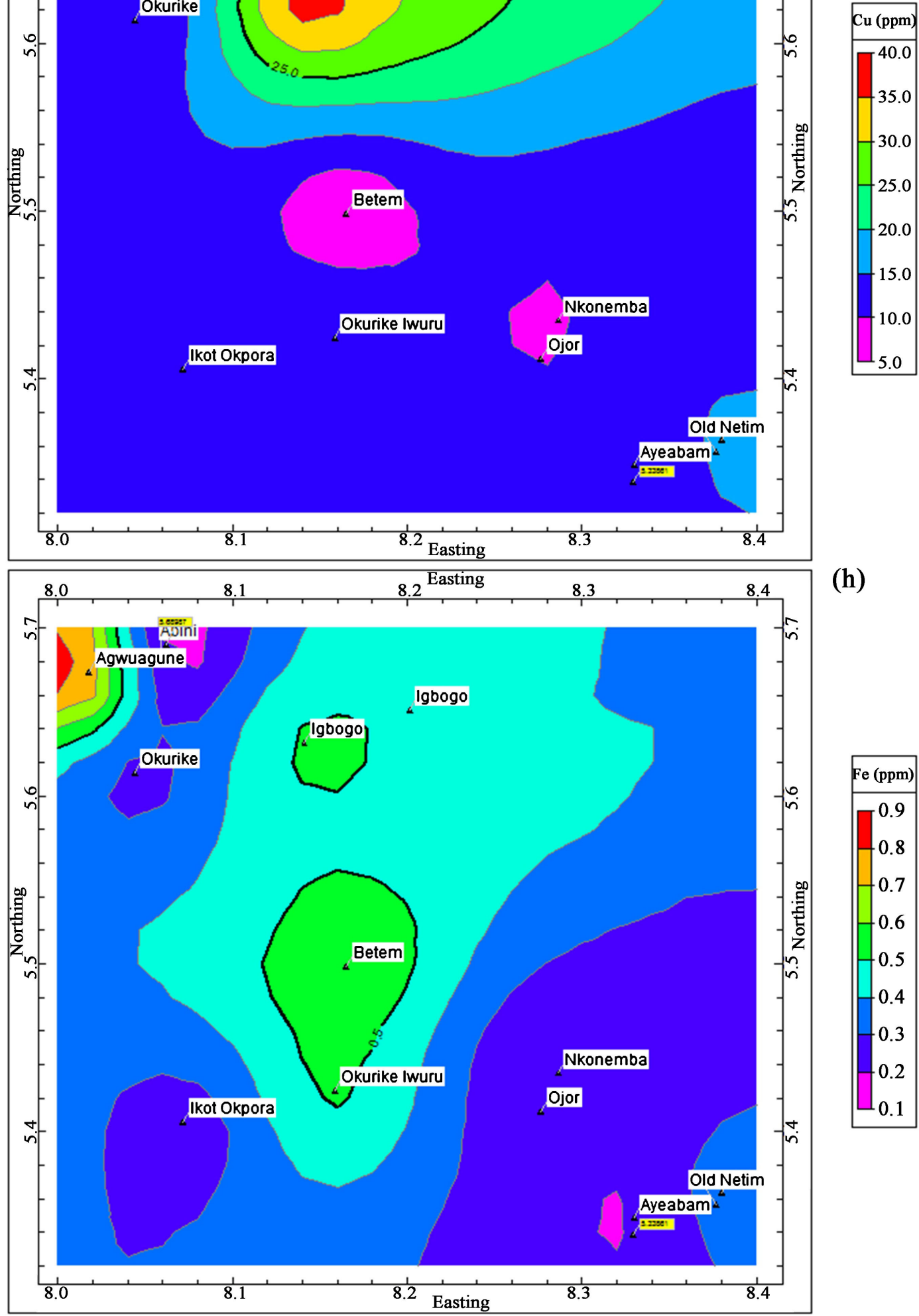

(h)

\begin{tabular}{|l|}
\hline Fe (ppm) \\
\hline${ }^{0.9}$ \\
0.8 \\
0.7 \\
0.6 \\
0.5 \\
0.4 \\
0.3 \\
0.2 \\
0.1 \\
\hline
\end{tabular}



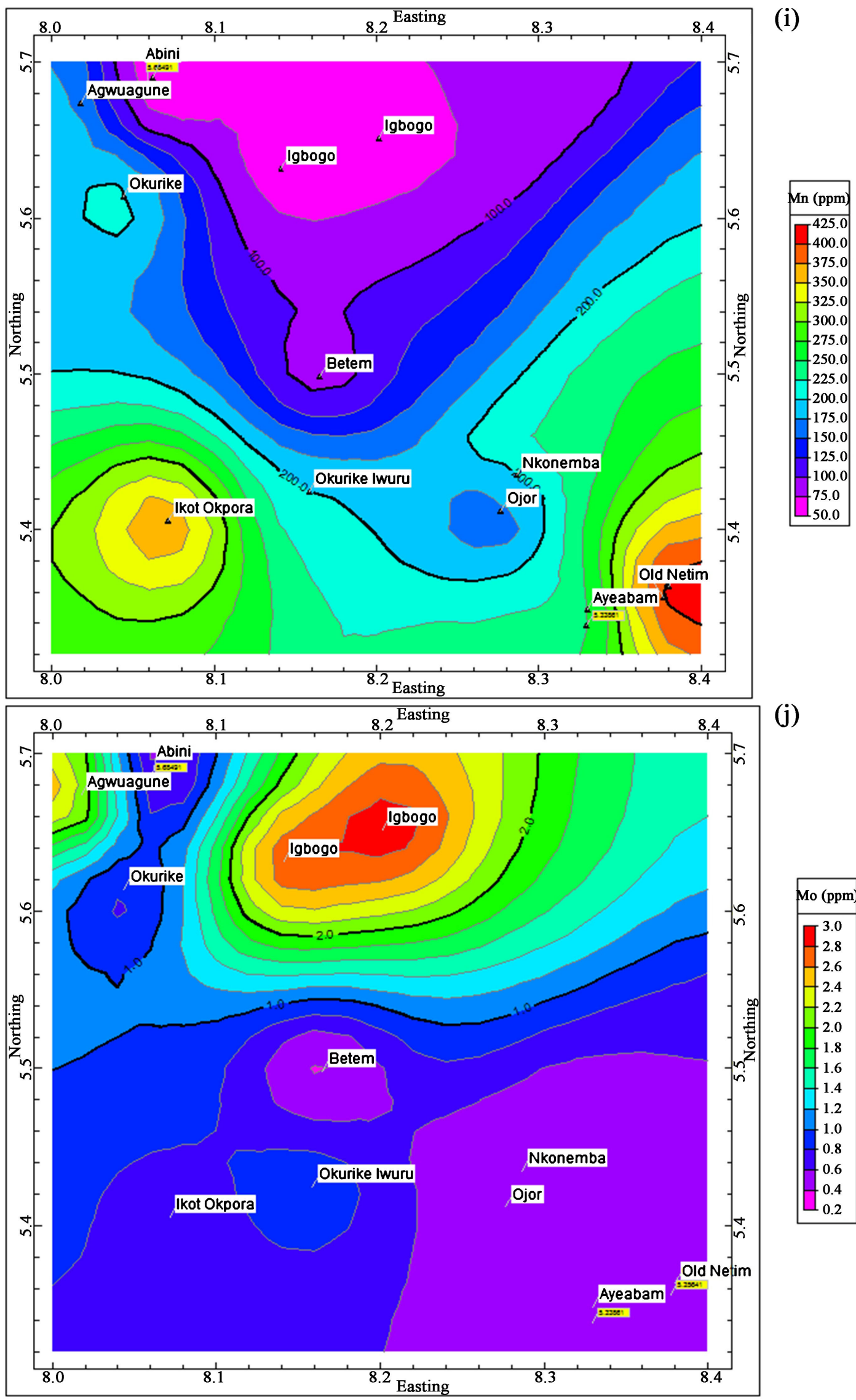


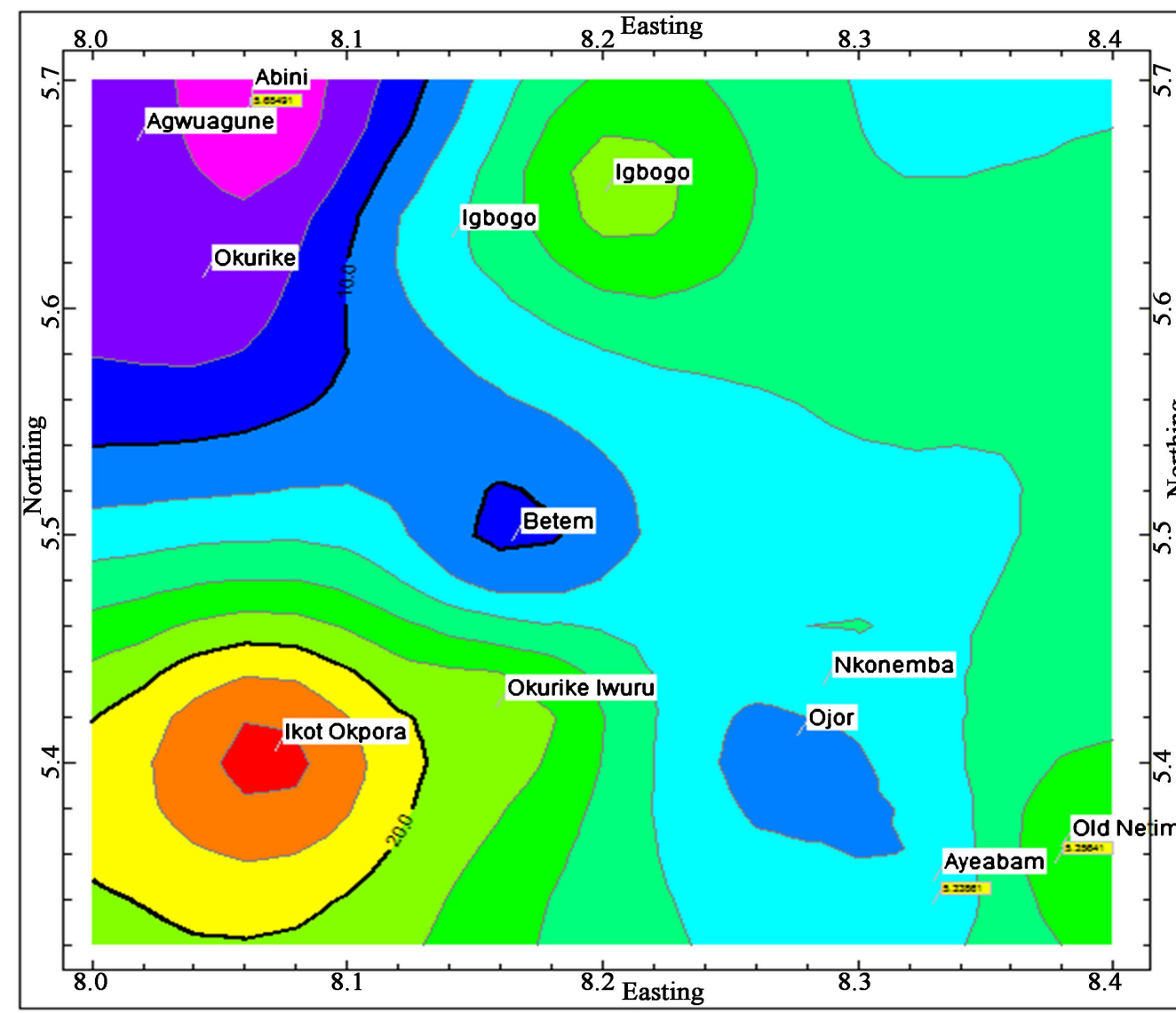

(k)

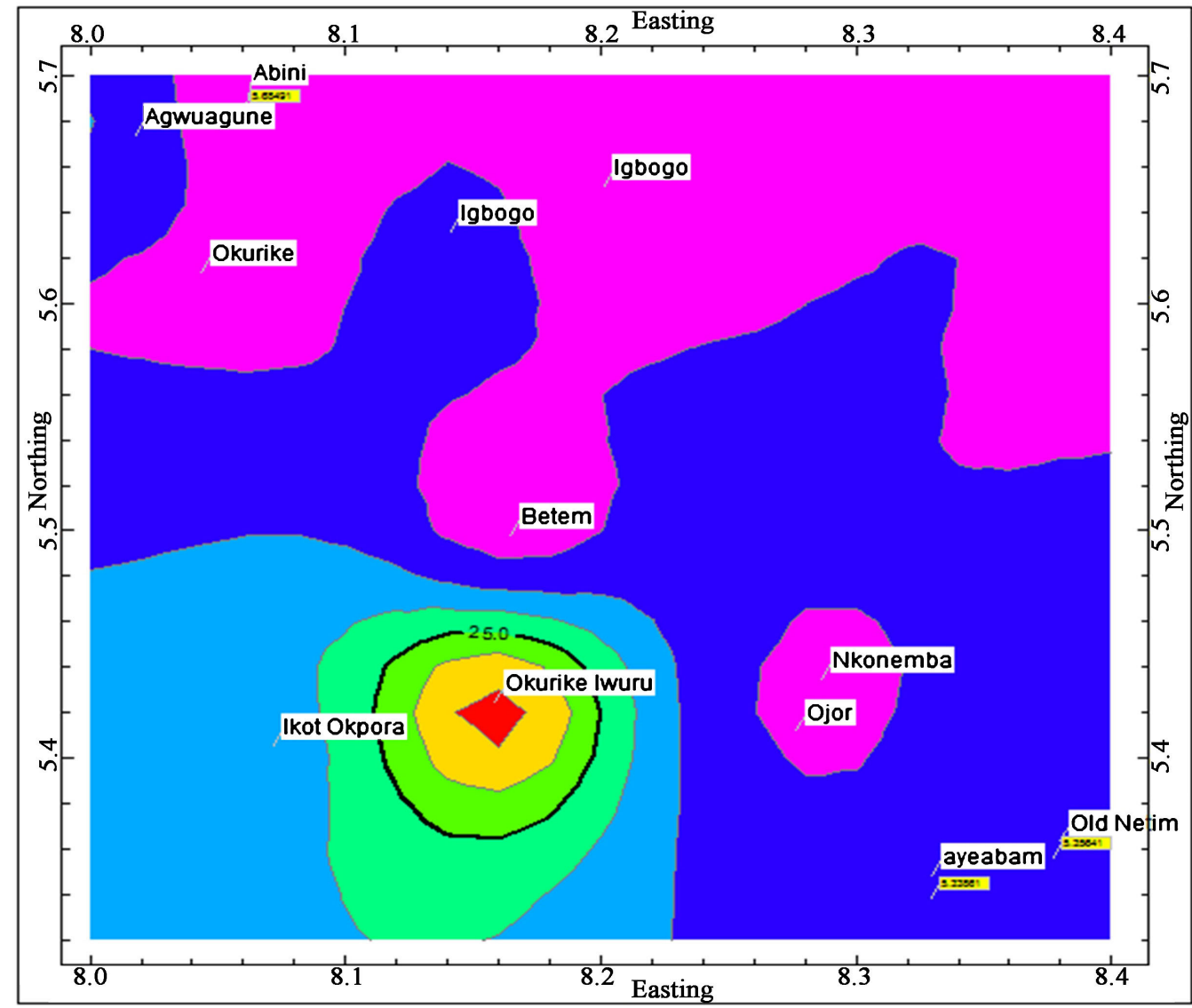

(1)

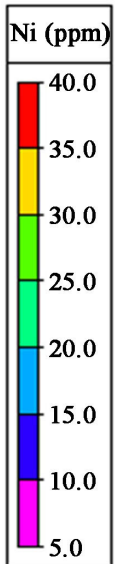



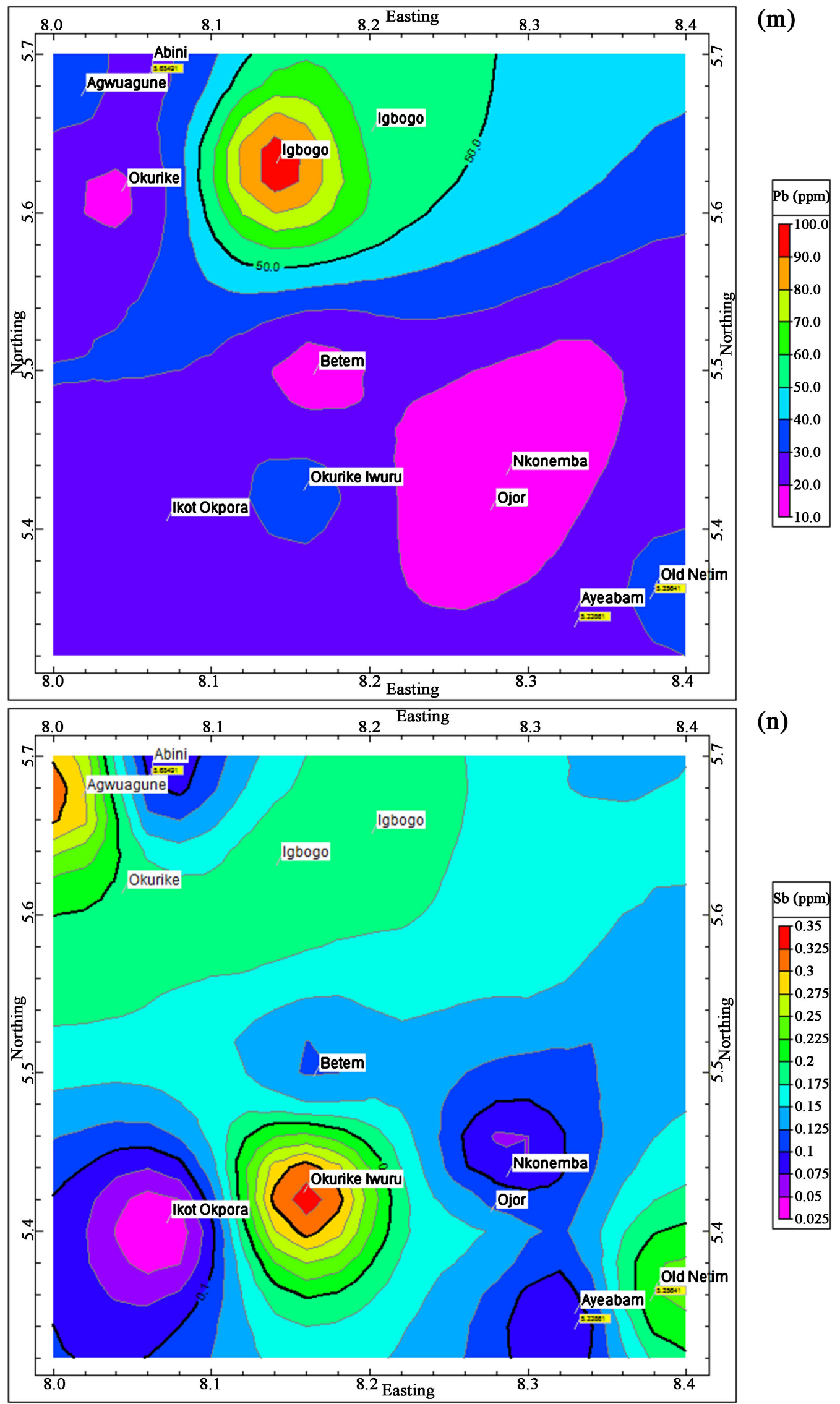

(n)

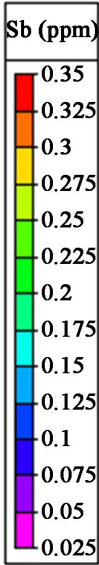




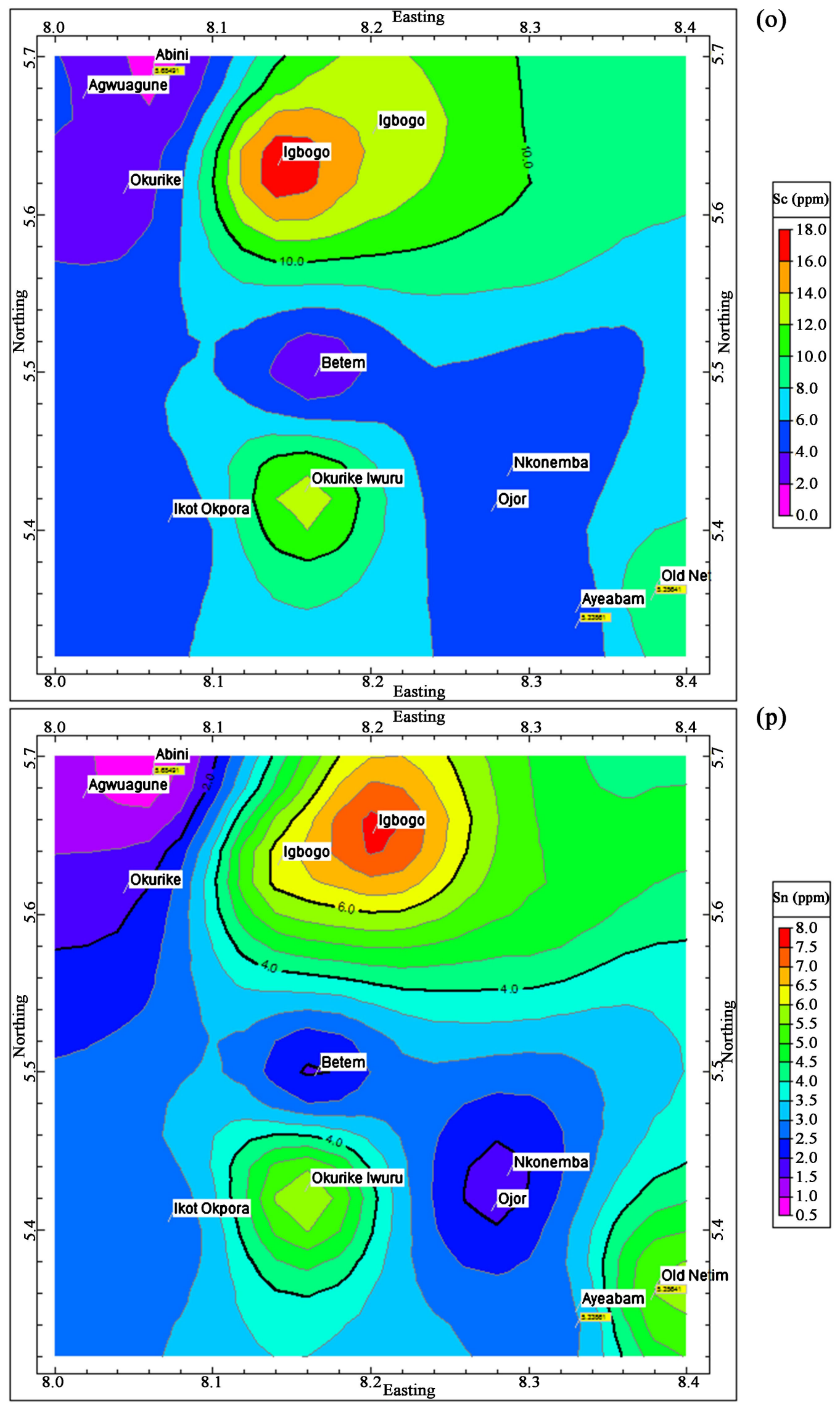



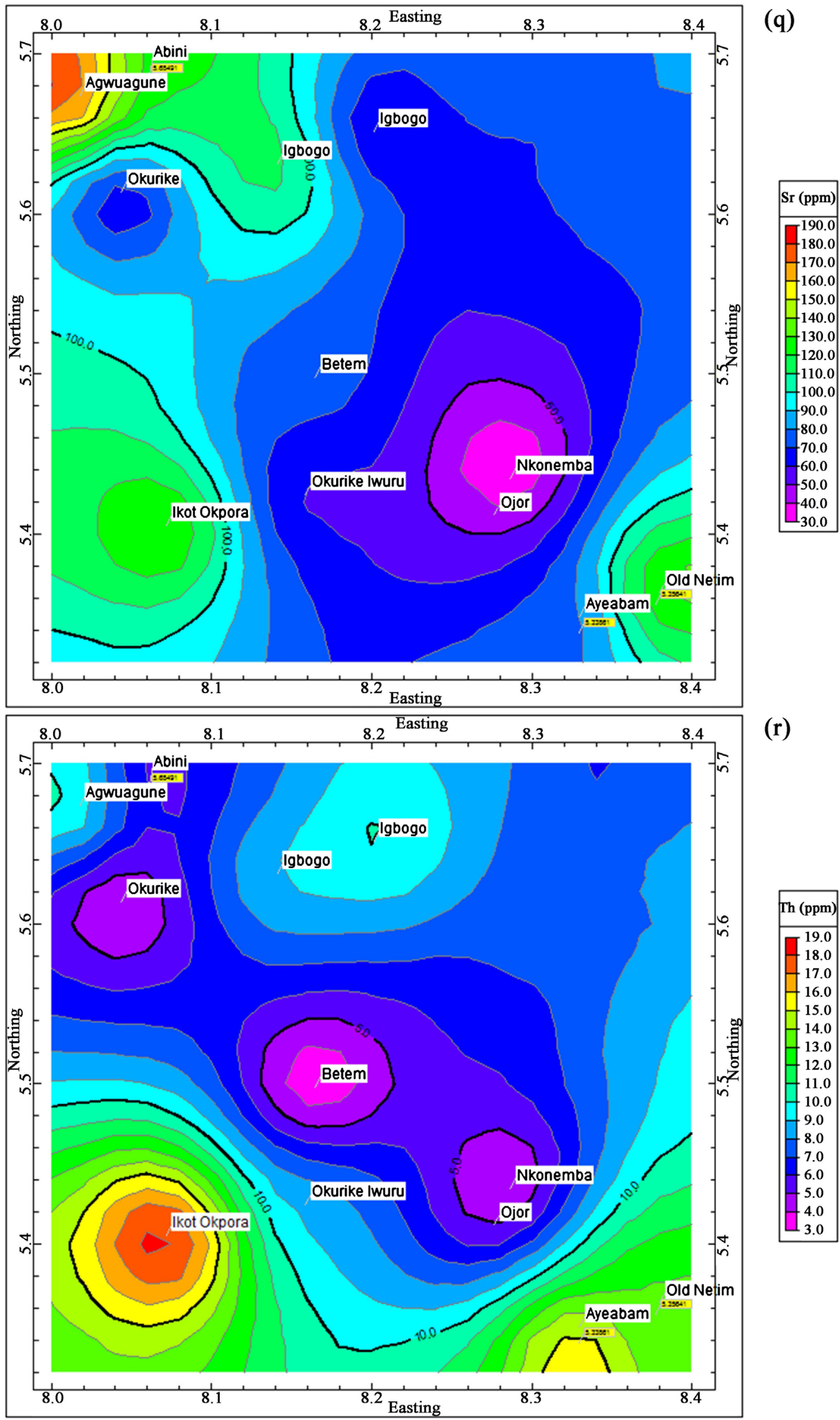

(r)

\begin{tabular}{|c|}
\hline Th (ppm) \\
\hline 19.0 \\
\hline 18.0 \\
\hline 17.0 \\
\hline 16.0 \\
\hline 15.0 \\
\hline 14.0 \\
\hline 13.0 \\
\hline 12.0 \\
\hline 11.0 \\
\hline 10.0 \\
\hline 9.0 \\
\hline 8.0 \\
7.0 \\
\hline 6.0 \\
\hline 5.0 \\
\hline 4.0 \\
3.0 \\
\hline
\end{tabular}




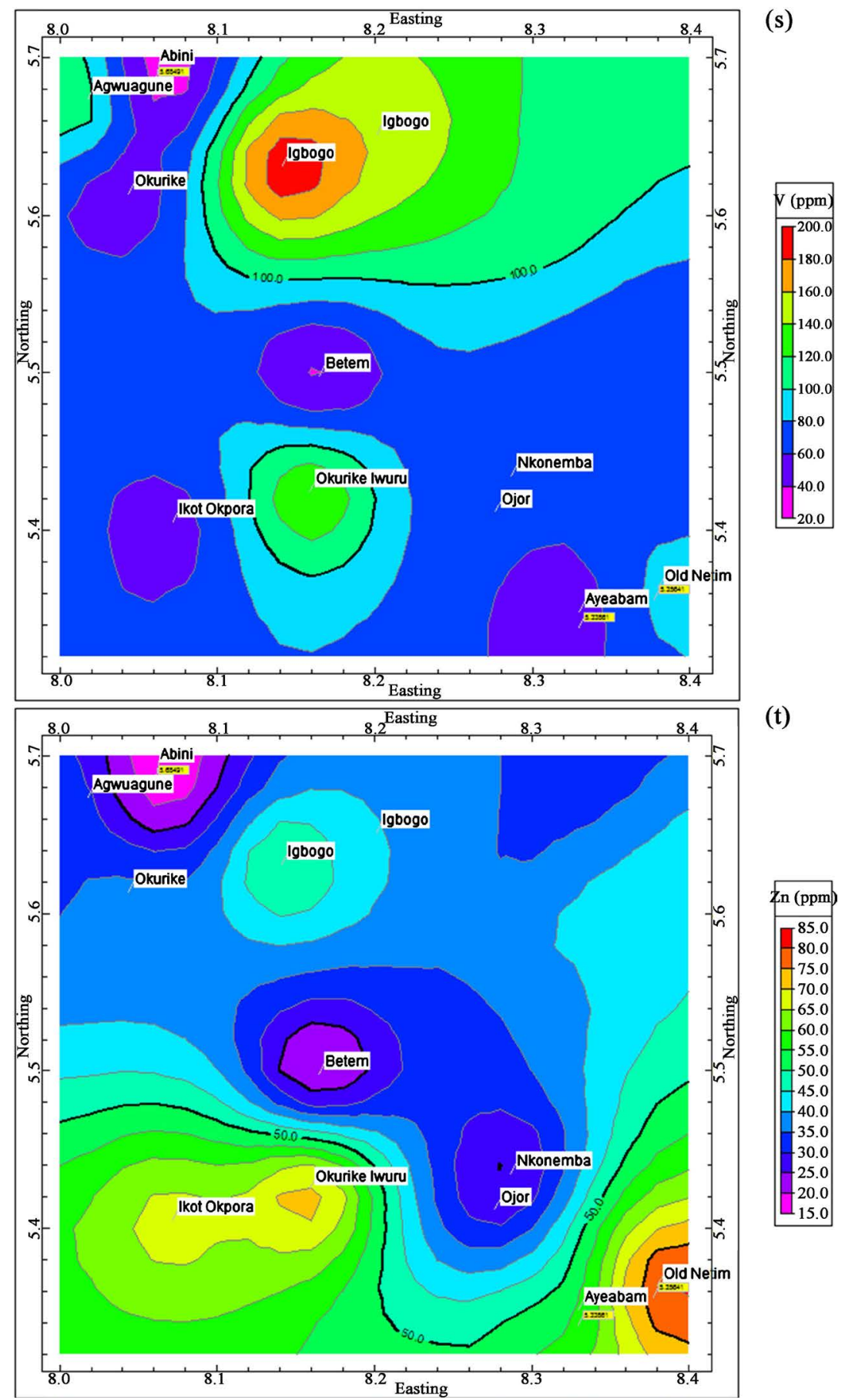

Figure 3. (a) Distribution pattern for $\mathrm{Al}$ in the area; (b) Distribution pattern for As in the area; (c) Distribution pattern for Ba in the area; (d) Distribution pattern for Ce in the area; (e) Distribution pattern for Co in the area; (e) Distribution pattern for $\mathrm{Cr}$ in the area; (g) Distribution pattern for $\mathrm{Cu}$ in the area; (h) Distribution pattern for Fe in the area; (i) Distribution pattern for $\mathrm{Mn}$ in the area; (j) Distribution pattern for Mo in the area; (k) Distribution pattern for $\mathrm{Nb}$ in the area; (l) Distribution pattern for $\mathrm{Ni}$ in the area; (m) Distribution Pattern for $\mathrm{Pb}$ in the area; (n) Distribution pattern for $\mathrm{Sb}$ in the area; (o) Distribution pattern for Sc in the area; (p) Distribution pattern for Sn in the study area; (q) Distribution pattern for Sr in the area; (r) Distribution pattern for Th in the area; (s) Distribution pattern for $\mathrm{V}$ in the area; $(\mathrm{t})$ Distribution pattern of $\mathrm{Zn}$ in the area. 
Table 3. Summary of Contamination factor of heavy metals in the Quarry and Barite mines area.

\begin{tabular}{|c|c|c|c|c|c|c|}
\hline & \multicolumn{3}{|c|}{ Quarry area } & \multicolumn{3}{|c|}{ Barite mine area } \\
\hline & Range & Mean & Remark & Range & Mean & Remark \\
\hline $\mathrm{Al}$ & $0.020-0.180$ & 0.080 & Low & $0.020-0.130$ & 0.08 & Low \\
\hline As & $0.100-1.000$ & 0.200 & Low & $0.100-2.000$ & 0.73 & Low \\
\hline $\mathrm{Ba}$ & $0.300-1.410$ & 0.960 & Low & $0.300-12.930$ & 4.59 & Considerable \\
\hline $\mathrm{Ce}$ & $0.070-1.230$ & 0.510 & Low & $0.290-0.620$ & 0.45 & Low \\
\hline Co & $0.500-2.260$ & 1.010 & Moderate & $0.120-0.880$ & 0.40 & Low \\
\hline $\mathrm{Cr}$ & $0.200-2.620$ & 1.030 & Moderate & $0.070-2.520$ & 0.99 & Low \\
\hline $\mathrm{Cu}$ & $0.110-0.440$ & 0.510 & Low & $0.090-0.980$ & 0.42 & Low \\
\hline $\mathrm{Fe}$ & $0.010-0.130$ & 0.060 & Low & $0.010-0.240$ & 0.07 & Low \\
\hline Mn & $0.070-0.520$ & 0.290 & Low & $0.010-0.270$ & 0.12 & Low \\
\hline Mo & $0.070-0.330$ & 0.180 & Low & $0.030-1.070$ & 0.58 & Low \\
\hline $\mathrm{Nb}$ & $0.510-2.360$ & 1.390 & Moderate & $0.220-1.880$ & 0.87 & Low \\
\hline $\mathrm{Ni}$ & $0.060-0.640$ & 0.210 & Low & $0.030-0.180$ & 0.09 & Low \\
\hline $\mathrm{Pb}$ & $0.380-1.960$ & 1.140 & Moderate & $0.470-5.850$ & 2.23 & Moderate \\
\hline $\mathrm{Sb}$ & $0.070-0.270$ & 0.100 & Low & $0.070-0.270$ & 0.12 & Low \\
\hline Sc & $0.080-1.150$ & 0.480 & Low & $0.080-1.620$ & 0.79 & Low \\
\hline Sn & $0.430-2.270$ & 1.130 & Moderate & $0.130-2.800$ & 1.06 & Moderate \\
\hline $\mathrm{Sr}$ & $0.050-0.600$ & 0.280 & Low & $0.130-0.700$ & 0.37 & Low \\
\hline Th & $0.180-1.730$ & 0.890 & Low & $0.220-1.010$ & 0.63 & Low \\
\hline $\mathrm{V}$ & $0.160-1.190$ & 0.520 & Low & $0.060-1.750$ & 0.77 & Low \\
\hline $\mathrm{Zn}$ & $0.130-0.940$ & 0.560 & Low & $0.130-0.590$ & 0.35 & Low \\
\hline
\end{tabular}

Table 4. Summary of enrichment factor of heavy metals in the quarry and barite mines area.

\begin{tabular}{|c|c|c|c|c|c|c|c|c|}
\hline \multirow{2}{*}{ Heavy metals } & \multicolumn{4}{|c|}{ Quarry area } & \multicolumn{4}{|c|}{ Barite mines } \\
\hline & Min & Max & Mean & Remark & $\operatorname{Max}$ & Min & Mean & Remark \\
\hline $\mathrm{Al}$ & 0.400 & 1.800 & 1.100 & Deficient to minimal & 0.300 & 2.600 & 1.550 & Deficient to minimal \\
\hline As & 0.900 & 7.500 & 1.730 & Deficient to minimal & 3.800 & 14.200 & 4.920 & Moderate \\
\hline $\mathrm{Ba}$ & 8.200 & 53.200 & 18.870 & Significant & 7.000 & 111.400 & 65.770 & Extremely High \\
\hline $\mathrm{Ce}$ & 0.600 & 28.700 & 11.210 & Significant & 2.600 & 35.400 & 10.670 & Significant \\
\hline Co & 6.100 & 130.200 & 27.530 & Very High & 1.000 & 48.700 & 15.270 & Significant \\
\hline $\mathrm{Cr}$ & 3.000 & 4.000 & 17.570 & Significant & 5.500 & 21.700 & 11.630 & Significant \\
\hline $\mathrm{Cu}$ & 0.800 & 7.500 & 4.680 & Moderate & 1.200 & 32.800 & 9.630 & Significant \\
\hline Mo & 0.500 & 5.000 & 3.260 & Moderate & 3.800 & 9.700 & 5.970 & Significant \\
\hline $\mathrm{Nb}$ & 5.400 & 49.400 & 25.770 & Very High & 3.400 & 27.600 & 15.330 & Significant \\
\hline
\end{tabular}


Continued

\begin{tabular}{cccccccccc}
\hline $\mathrm{Ni}$ & 0.400 & 5.500 & 3.520 & Moderate & 1.000 & 4.400 & 2.230 & Moderate \\
$\mathrm{Pb}$ & 4.500 & 55.200 & 21.370 & Very High & 7.500 & 119.700 & 45.670 & Extremely High \\
$\mathrm{Sb}$ & 0.500 & 2.900 & 1.220 & Deficient to minimal & 1.100 & 8.000 & 2.430 & Moderate \\
$\mathrm{Sc}$ & 0.600 & 11.600 & 7.110 & Significant & 1.600 & 14.000 & 6.450 & Significant \\
$\mathrm{Sn}$ & 3.300 & 34.300 & 19.070 & Significant & 1.500 & 26.300 & 13.980 & Significant \\
$\mathrm{Sr}$ & 1.500 & 13.000 & 5.310 & Significant & 1.600 & 37.500 & 11.330 & Significant \\
$\mathrm{Th}$ & 1.400 & 48.000 & 18.410 & Significant & 4.300 & 48.500 & 15.180 & Significant \\
$\mathrm{V}$ & 1.200 & 14.200 & 8.900 & Significant & 4.800 & 15.100 & 16.900 & Significant \\
$\mathrm{Zn}$ & 1.000 & 18.200 & 10.090 & Significant & 1.700 & 9.500 & 4.500 & Moderate \\
\hline
\end{tabular}

with extremely high enrichment in $\mathrm{Ba}$ and $\mathrm{Pb}$. This results indicates that the quarry area is contaminated with $\mathrm{Ba}, \mathrm{Ce}, \mathrm{Co}, \mathrm{Cr}, \mathrm{Mn}, \mathrm{Nb}, \mathrm{Pb}, \mathrm{Sc}, \mathrm{Sn}, \mathrm{Sr}, \mathrm{Th}, \mathrm{V}$ and $\mathrm{Zn}$ while the barite area is contaminated with $\mathrm{Ba}, \mathrm{Ce}, \mathrm{Co}, \mathrm{Cr}, \mathrm{Co}, \mathrm{Mo}, \mathrm{Nb}$, $\mathrm{Pb}, \mathrm{Sc}, \mathrm{Sn}, \mathrm{Sr}$, Th and $\mathrm{V}$, since the enrichment factor of these heavy metals is greater than 5 in these areas (Harikumar \& Jisha, 2010).

\subsection{Factor Analysis}

Factor analysis was carried out using all the twenty (20) elements analyzed from soil samples within the study area. A four factor model that accounted for $79.15 \%$ of the total data variance was considered (Table 5), in view of the underlying geology, environmental evidence and land use pattern in the area. Only variables with loading $>0.5$, were considered significant members of a particular factor. The resulting varimax is summarized in Table 5. The factors extracted are as follows;

Factor 1: The factor is characterized by high loadings of $\mathrm{As}, \mathrm{Ba}, \mathrm{Co}, \mathrm{Cr}, \mathrm{Cu}$, $\mathrm{Fe}, \mathrm{Mo}, \mathrm{Nb}, \mathrm{Pb}, \mathrm{Sb}, \mathrm{Sc}, \mathrm{Sn}, \mathrm{V}, \mathrm{Zn}$. This factor accounts for $40.776 \%$ of the total data variance and are interpreted to have been derived mainly from gneissic rocks. This is indicated with the higher loadings by $\mathrm{Ba}, \mathrm{Mo}, \mathrm{Pb}, \mathrm{Sc}$ and $\mathrm{Sn}$, which were also significantly enriched in these areas. The presence of $\mathrm{Nb}, \mathrm{Sb}$ and $\mathrm{Zn}$ indicates the influence of granodiorite and schist which are associated with the basement rocks, while the negative loading of Co suggest the depletion of this element in the area.

Factor 2: The factor is characterized by high loadings of Ce, $\mathrm{Mn}, \mathrm{Nb}, \mathrm{Th}, \mathrm{Zn}$. This factor accounts for $17.999 \%$ of the total data variance. The metals here derived majorly from the weathering of granodiorite and schist mainly from the quarry areas as indicated by the high loading of $\mathrm{Zn}$ and $\mathrm{Th}$.

Factor 3: The factor is characterized by Al, Ce, Ni, Sb. This factor accounts for $11.207 \%$ of the total data variance and it is interpreted to be related to depletion of these elements ( $\mathrm{Al}, \mathrm{Ni}$ and $\mathrm{Sb}$ ) in the area, as indicated by their negative loadings. The positive value of Ce suggests its significant enrichment in the area.

Factor 4: There is high negative loadings for Fe, Sr. this factor accounts for 
Table 5. Factor analysis for measured heavy metals.

\begin{tabular}{|c|c|c|c|c|}
\hline Variables & Factor 1 & Factor 2 & Factor 3 & Factor 4 \\
\hline $\mathrm{Al}$ & 0.485 & -0.080 & -0.608 & -0.078 \\
\hline As & 0.596 & -0.415 & 0.355 & 0.313 \\
\hline $\mathrm{Ba}$ & 0.762 & -0.440 & 0.312 & -0.164 \\
\hline $\mathrm{Ce}$ & 0.222 & 0.694 & 0.587 & -0.155 \\
\hline Co & -0.620 & 0.005 & -0.257 & 0.235 \\
\hline $\mathrm{Cr}$ & 0.558 & -0.204 & -0.157 & 0.238 \\
\hline $\mathrm{Cu}$ & 0.861 & -0.262 & 0.243 & 0.194 \\
\hline $\mathrm{Fe}$ & 0.577 & -0.100 & -0.365 & -0.546 \\
\hline $\mathrm{Mn}$ & 0.113 & 0.850 & -0.149 & 0.080 \\
\hline Mo & 0.793 & -0.299 & 0.158 & -0.282 \\
\hline $\mathrm{Nb}$ & 0.559 & 0.600 & 0.078 & 0.348 \\
\hline $\mathrm{Ni}$ & 0.477 & 0.455 & -0.537 & 0.013 \\
\hline $\mathrm{Pb}$ & 0.820 & -0.257 & 0.267 & -0.062 \\
\hline $\mathrm{Sb}$ & 0.610 & 0.024 & -0.599 & -0.287 \\
\hline Sc & 0.911 & -0.058 & -0.086 & 0.278 \\
\hline Sn & 0.825 & 0.100 & -0.075 & 0.392 \\
\hline $\mathrm{Sr}$ & 0.243 & 0.253 & 0.190 & -0.816 \\
\hline Th & 0.380 & 0.746 & 0.418 & -0.135 \\
\hline $\mathrm{V}$ & 0.935 & -0.159 & -0.099 & -0.005 \\
\hline $\mathrm{Zn}$ & 0.589 & 0.721 & -0.130 & 0.152 \\
\hline Eigen Value & 8.155 & 3.600 & 2.241 & 1.833 \\
\hline$\%$ variance & 40.776 & 17.999 & 11.207 & 9.164 \\
\hline Cumm. Eigen val. & 8.155 & 11.755 & 13.966 & 15.829 \\
\hline Cumm. \% Variance & 40.776 & 58.775 & 69.982 & 79.146 \\
\hline
\end{tabular}

9.164\% of the total data variance, and it is interpreted to be related to weathering, since these metals are found to concentrate more within the sedimentary basin.

\section{Conclusion}

The investigation revealed that the average concentration of $(\mathrm{Ba}, \mathrm{Co}, \mathrm{Cr}, \mathrm{Nb}$ and $\mathrm{Sn})$ and $(\mathrm{Ba}, \mathrm{Pb}$ and $\mathrm{Sn})$ are greater than the average shale value in the quarry and barite mine areas respectively. And the mean heavy metals dominance is in the order $\mathrm{Ba}>\mathrm{Mn}>\mathrm{Cr}>\mathrm{Sr}>\mathrm{V}>\mathrm{Zn}>\mathrm{Ce}>\mathrm{Pb}>\mathrm{Co}>\mathrm{Nb}>\mathrm{Cu}>\mathrm{Ni}>\mathrm{Th}>$ $\mathrm{Sc}>\mathrm{Sn}>\mathrm{As}>\mathrm{Mo}>\mathrm{Al}>\mathrm{Fe}>\mathrm{Sb}$ and $\mathrm{Ba}>\mathrm{Sr}>\mathrm{Mn}>\mathrm{V}>\mathrm{Cr}>\mathrm{Pb}>\mathrm{Ce}>\mathrm{Zn}>$ $\mathrm{Cu}>\mathrm{Nb}>\mathrm{Ni}>\mathrm{Sc}>\mathrm{Co}>\mathrm{Th}>\mathrm{As}>\mathrm{Sn}>\mathrm{Mo}>\mathrm{Al}>\mathrm{Fe}>\mathrm{Sb}$ around the quarries and barite mine areas respectively. The result of the contamination factor indicate that the quarry area is lowly contaminated with $\mathrm{Ni}, \mathrm{Sb}, \mathrm{Sc}, \mathrm{Sr}, \mathrm{Th}, \mathrm{V}$ and $\mathrm{Zn}$, 
moderately contaminated with $\mathrm{Co}, \mathrm{Cr}, \mathrm{Nb}$. While the barite mine area is lowly contaminated with $\mathrm{Al}, \mathrm{As}, \mathrm{Ce}, \mathrm{Co}, \mathrm{Cr}, \mathrm{Cu}, \mathrm{Fe}, \mathrm{Mn}, \mathrm{Nb}, \mathrm{Ni}, \mathrm{Sb}, \mathrm{Sc}, \mathrm{Sr}, \mathrm{Th}, \mathrm{V}$ and $\mathrm{Zn}$, moderately contaminated with $\mathrm{Pb}$ and $\mathrm{Sn}$, and considerably contaminated with $\mathrm{Ba}$. In terms of metal enrichment, the quarry area is deficient in $\mathrm{Al}$, As and $\mathrm{Sb}$, moderately enriched in $\mathrm{Cu}$, Mo and $\mathrm{Ni}$, significantly enriched in $\mathrm{Ba}, \mathrm{Ce}, \mathrm{Cr}$, $\mathrm{Mn}, \mathrm{Sc}, \mathrm{Sn}, \mathrm{Th}, \mathrm{V}$ and $\mathrm{Zn}$, and very high in $\mathrm{Co}, \mathrm{Nb}$ and $\mathrm{Pb}$ enrichment. While the barite area is minimally enriched with $\mathrm{Al}$, moderately enriched in As, $\mathrm{Mn}$, $\mathrm{Ni}, \mathrm{Sb}$ and $\mathrm{Zn}$, significantly enrich in $\mathrm{Ce}, \mathrm{Co}, \mathrm{Cr}, \mathrm{Cu}, \mathrm{Mn}, \mathrm{Mo}$ and $\mathrm{Nb}$, extremely high in enrichment of $\mathrm{Ba}$ and $\mathrm{Pb}$. The result of the factor analysis and spatial distribution of the heavy metals indicates that the metal concentration and enrichment were controlled by the rock types, anthropogenic activities and weathering.

\section{Conflicts of Interest}

The authors declare no conflicts of interest regarding the publication of this paper.

\section{References}

Adamu, C. I., Nganje, T. N., \& Edet, A. (2015a). Heavy Metal Contamination and Health Risk Assessment Associated with Abandoned Barite Mines in Cross River State, Southeastern Nigeria. Environmental Nanotechnology, Monitoring \& Management, 3, 10-21. https://doi.org/10.1016/j.enmm.2014.11.001

Adamu, C. I., Nganje, T. N., \& Edet, A. (2015b). Major and Trace Elements Pollution of Sediments Associated with Abandoned Barite Mines in Parts of Oban Massif and Mamfe Embayment, SE Nigeria. Journal of Geochemical Exploration, 151, 17-33. https://doi.org/10.1016/j.gexplo.2014.12.010

Bölücek, C. (2007). Environmental Contamination in the Keban Mining District, Eastern Turkey. The Arabian Journal for Science and Engineering, 32, 3-18.

Bond, A. R. (2009). Environmental Geochemistry. 1993-2008. Microsoft Corporation.

CRBDA (2008). Hydrogeological Survey of Lower Cross River Basin: Final Report (158 p). Calabar, Nigeria: Cross River Basin Development Authority.

Ekweme, B. N., \& Akpeke, G. (2012). Occurrence and Distribution of Barite Mineralization in Cross River State, Southeastern Nigeria. Global Journal of Geological Sciences, 10, 85-98.

Ekwueme, B. N. (1995). Geochemistry of Crystalline Basement Rocks in S. W. Ugep, Nigeria. Global Journal of Geological Sciences, 1, 143-157. https://doi.org/10.4314/gjgs.v1i2.18663

Ekwueme, B. N., \& Onyeagocha, A. C. (1986). Geochemistry of Meta-Sedimentary Rocks of Uwet Area, Oban Massif, Southeastern Nigeria. Geologische Rundschau, 75, 411-420. https://doi.org/10.1007/BF01820620

Ekwueme, B. N., Nyong, E. E., \& Petters, S. W. (1995). Geological Excursion Guidebook to Oban Massif, Calabar Flank and Ikom Mamfe Embayment, Southeastern Nigeria. Calabar: Dec. Ford Publishers Limited.

Harikumar, P. S., \& Jisha, T. S. (2010). Distribution Pattern of Trace Metal Pollutants in the Sediments of an Urban Wetland in the Southwest Coast of India. International Journal of Engineering Science and Technology, 2, 840-850.

Huang, S., Yuang, C., Li, Q., Yang, Y., Tang, C., Ouyang, K., \& Wang, B. (2017). Distribution and Assessment of Heavy Metals in Soils from a Typical Pb-Zn Mining Area. 
Polish Journal of Environmental Study, 26, 1105-1112.

https://doi.org/10.15244/pjoes/68424

Huss, J. (2011). Health Hazards of Heavy Metals and Other Metals. Luxemburg: Socialist Group. Doc. 12613.

Iloeje, N. P. (1991). A New Geography of Nigeria. Lagos: Longman.

Lenntech, B. V. (2011). Chemical Properties, Health and Environmental Effects of Metals.

Martin, S., \& Griswold, W. (2009). Human Health Effects of Heavy Metals. http://www.engg.ksu.edu/

Nganje, T. N., Adamu, C. I., \& Ukpong, E. E. (2010). Heavy Metal Concentrations in Soils and Plants in the Vicinity of Arufu Lead-Zinc Mine, Middle Benue Trough, Nigeria. Chinese Journal of Geochemistry, 29, 167-174. https://doi.org/10.1007/s11631-010-0167-x

Oancea, S., Foca, N., \& Airinei, A. (2005). Effects of Heavy Metals on Plant Growth and Photosynthetic Activity. Analele Ştiințifice ale Universităţii “AL. I. CUZA” IAŞI, 107-110.

Ochelebe, I., Ekwere, A. S., \& Ekwere, S. J. (2017). Environmental Implication of the Distribution of Heavy Metals in Soils and Water in Okpoma Area, Southeastern Nigeria. International Journal of Science and Engineering Investigations, 6, 105-113.

Rafiei, B., Bakhtiari, M., Hashemi, M., \& Khodei, A. S. (2010). Distribution of Heavy Metals around the Dashkasan Au Mine. International Journal of Environmental Research, 4, 647-654.

Rahman, A., Persson, L., \& Nermell, B. (2010). Arsenic Exposure and Risk of Spontaneous Abortion, Stillbirth, and Infant Mortality. Epidemiology, 21, 797-804.

https://doi.org/10.1097/EDE.0b013e3181f56a0d

Simex, S. A., \& Helz, G. R. (1981). Regional Geochemistry of Trace Elements in Chesapeake Bay. Environmental Geochemistry, 3, 315-323. https://doi.org/10.1007/BF02473521

Singh, J., \& Kalamdhad, A. (2011). Effect of Heavy Metals on Soils, Plants, Human Health and Aquatic Life. International Journal of Research in Chemistry and Environment, 1, 15-21.

Sun, Z., Xie, X., Wung, P., Hu, Y., \& Cheng, H. (2018). Heavy Metal Pollution Caused by Small Scale Mining Activities: A Case Study from a Polymetallic Mine in South China. Science of the Total Environment, 639, 217-227. https://doi.org/10.1016/j.scitotenv.2018.05.176

Sutherland, R. A. (2000). Bed Sediment-Associated Trace Metals in an Urban Stream Oahu, Hawaii. Environmental Geology, 39, 611-637. https://doi.org/10.1007/s002540050473

Tian, L. L. (2009). Effects of Gestational Cadmium Exposure on Pregnancy Outcome and Development in the Offspring at Age 4.5 Years. Biological Trace Element Research, 132, 51-59. https://doi.org/10.1007/s12011-009-8391-0

Wedepohl, K. H. (1971). Environmental Influences on the Chemical Composition of Shale and Clays. In L. H. Ahrens, F. Press, S. K. Runcom, \& H. C. Urey (Eds.), Physics and Chemistry of the Earth (Vol. 8, pp. 305-335). Oxford: Pergamon Press. https://doi.org/10.1016/0079-1946(71)90020-6

Zarei, I., Pourkhabbaz, A., \& Khuzestani, R. B. (2014). An Assessment of Metal Contamination Risk in Sediments of Hara Biosphere Reserve, Southern Iran with a Focus on Application of Pollution Indicators. Environmental Monitoring and Assessment volume, 186, 6047-6060. https://doi.org/10.1007/s10661-014-3839-x 